\title{
Petrography and Geochemistry of Basement Rocks Drilled from Snail, Yamanaka, Archaean, and Pika Hydrothermal Vent Sites at the Southern Mariana Trough by Benthic Multi-Coring System (BMS)
}

\author{
Kentaro Nakamura, Hiroshi Sato, Patricia Fryer, and Tetsuro Urabe, \\ TAIGA 10M Shipboard Scientific Party
}

\begin{abstract}
Petrographic and geochemical characteristics of drill core and surface rock samples from the four hydrothermal vent sites of the Yamanaka, Snail, Archaean, and Pika sites at the Southern Mariana Trough (SMT) are described in order to clarify the geological background of hydrothermal activities. The core samples were drilled by the Benthic Multicoring System (BMS), penetrating up to $\sim 8 \mathrm{~m}$ below seafloor. The recovered samples included both basement rocks and sulfide ores. The basement rocks are further subdivided into basaltic andesite and andesite, most of which are recovered from on-axis and off-axis regions of the SMT, respectively. All of the rocks are characterized by relative enrichment of large-ion lithophile elements with noticeable depletion of $\mathrm{Nb}$ and $\mathrm{Ta}$, suggestive of
\end{abstract}

The online version of this chapter (doi:10.1007/978-4-431-54865-2_41) contains supplementary material, which is available to authorized users.

K. Nakamura $(\bowtie)$

Precambrian Ecosystem Laboratory (PEL), Japan Agency

for Marine-Earth Science and Technology (JAMSTEC),

2-15 Natsushima, Yokosuka, Kanagawa 237-0061, Japan

Submarine Hydrothermal System Research Group, Japan Agency for Marine-Earth Science and Technology (JAMSTEC),

2-15 Natsushima, Yokosuka, Kanagawa 237-0061, Japan

Department of Systems Innovation, School of Engineering,

The University of Tokyo, 7-3-1 Hongo, Bunkyo-ku,

Tokyo 113-8656, Japan

e-mail: kentaron@sys.t.u-tokyo.ac.jp

H. Sato

School of Business Administration, Senshu University, 2-1-1

Higashimita, Tama-ku, Kawasaki-shi, Kanagawa 214-8580, Japan

P. Fryer

School of Ocean and Earth Science and Technology (SOEST),

University of Hawai'i, 1680 East West Rd, Honolulu, HI 96822, USA

T. Urabe

Department of Earth and Planetary Sciences, The University of Tokyo,

7-3-1 Hongo, Bunkyo-ku, Tokyo 113-0033, Japan

TAIGA10M Shipboard Scientific Party (excluding Kentaro Nakamura, Patricia Fryer, and Tetsuro Urabe);

Shin Toyoda, Faculty of Science, Okayama University of Science,

1-1 Ridai, Okayama 700-0005, Japan

Junichi Miyazaki, Institute of Biogeosciences, Japan Agency for Marine-Earth Science and Technology (JAMSTEC), 2-15

Natsushima, Yokosuka, Kanagawa 237-0061, Japan

Nobutatsu Mochizuki, Priority Organization for Innovation and Excellence, Kumamoto University, 2-39-1 Kurokami, Kumamoto 860-8555, Japan

Shingo Kato, Department of Molecular Biology, Tokyo University of Pharmacy and Life Science, 1432-1 Horinouchi, Hachioji, Tokyo 192-0392, Japan

Teruhiko Kashiwabara, Graduate school of Science, Hiroshima University, 1-3-1 Kagamiyama, Higashi-hiroshima, Hiroshima 739-8526, Japan

Fumihiro Sato, Okayama University of Science, 1-1 Ridai, Okayama 700-0005, Japan

Sakiko Kikuchi, Graduate school of Science, Hiroshima University, 1-3-1 Kagamiyama, Higashi-hiroshima, Hiroshima 739-8526, Japan

Shigeshi Fuchida, Graduate School of Science, Osaka City University, 3-3-138, Sugimoto, Sumiyoshi, Osaka 558-8585, Japan

Takahito Nishiuchi, Graduate School of Natural Science and Technology, Okayama University, 3-1-1 Tsushima-naka, Okayama 700-8530, Japan

Jun Kawai, Graduate School of Engineering, Yokohama National University, 79-5 Tokiwadai, Hodogaya, Yokohama, Kanagawa 240-8501, Japan

Motoshige Date, Date City Institute of Funkawan Calture, 21-5 Tateyama, Date, Hokkaido 052-0031, Japan 
significant influence of subducted slab-derived components into the basement rocks both at the on- and off-axis hydrothermal vent sites. Major and trace element variations of the samples suggest that the Yamanaka, Snail, and Archaean rocks can be explained by a sequence of fractionation of an on-axis magma, whereas only the Pika rocks may be influenced by a different magma component, i.e., off-axis magmatism.

Keywords

Benthic Multi-coring System (BMS) - Geochemistry • Hydrothermal vent sites $\bullet$ Petrography $\bullet$ Southern Mariana Trough

\subsection{Introduction}

Chemical compositions of seafloor hydrothermal vent fluids have a significant impact on ocean chemistry, hydrothermal vent biological communities, and seafloor mineral deposits. For example, seafloor hydrothermal systems are long known to play a major role in elemental exchange between ocean and oceanic crust, affecting the composition of many elements in seawater (e.g., Edmond et al. 1979; Elderfield and Schultz 1996). Several chemical elements contained in hydrothermal fluids (e.g., $\mathrm{H}_{2} \mathrm{~S}, \mathrm{H}_{2}$, and $\mathrm{CH}_{4}$ ) also known to support a variety of biological communities sustained by primary production of chemolithoautotrophic microorganisms (e.g., Hessler and Kaharl 1995), which are essentially different from terrestrial ecosystems sustained by photosynthetic primary production. In recent years, furthermore, seafloor mineralization at hydrothermal vents, where metal sulfides precipitated from hydrothermal fluids are accumulated to form sulfide deposits, has attracted particular attention (e.g., Tivey 2007).

The chemical compositions of hydrothermal vent fluids are, in turn, influenced by composition of basement rocks, because hydrothermal fluids are developed by chemical reactions between penetrating seawater and basement rocks (e.g., Seyfried et al. 1991; Shock 1992). Understanding petrological and geochemical characteristics of the basement rocks is, therefore, important to elucidating chemical features of seafloor hydrothermal vent fluids. Here, we report petrographical and geochemical characteristics of basement rock samples drilled at/near the four hydrothermal vent sites (Snail, Yamanaka, Archaean, and Pika sites) located at the Southern Mariana Trough by using Benthic Multi-coring System (BMS).

\subsection{Geological Background}

The Mariana convergent margin system is located at the eastern boundary of the Philippine Sea region in the Western Pacific (Fig. 41.1). Subduction of the Pacific Plate beneath the Philippine Sea Plate began in the Eocene prior to 50 Ma (e. g., Seno and Maruyama 1984). By the Middle Oligocene
( 30 Ma), volcanism in response to subduction had built a volcanic arc that became localized along a relatively narrow chain, parallel to what would become the Izu-OgasawaraMariana trench system (Kobayashi and Nakada 1979). From $\sim 30$ to $20 \mathrm{Ma}$, a series of episodic arc building and rifting events occurred from west to east, and the Kyushu-Palau Ridge, Parece Vela Basin, and West Mariana Ridge were formed during this period. Since $10 \mathrm{Ma}$, extension has concentrated in the eastern basin of the system, the Mariana Trough.

The area of interest for this study includes hydrothermal systems both at spreading center and off-axis seamounts of the Southern Mariana Trough (SMT), approximately $110 \mathrm{~km}$ southwest of the island of Guam (Fig. 41.1). Within the Mariana Trough, this part of the spreading center is unusual in having morphology similar to fast-spreading mid-ocean ridges, despite the fact that the spreading rate in this part of the Mariana Trough is relatively low (45-65 mm/year full rate) (Martinez et al. 2000; Becker et al. 2010). It can be considered that arc magma is more readily available to this part of the spreading center region, because of the short distance between the back-arc spreading center and the arc volcanic front. The influence of the arc magma on the volcanisms at the spreading axis is likely the cause of the unusual ridge morphology. Indeed, Pearce et al. (2005) presented a systematic geochemical mapping for the whole area of the Mariana arc and trough system, showing that volcanic glasses from the middle to northern segments $\left(14-15^{\circ}, 17^{\circ}\right.$, and $\left.19.5^{\circ} \mathrm{N}\right)$ of the Mariana Trough have true mid-ocean ridge basalt (MORB) compositions without any subduction components, whereas those from southern part of the Mariana Trough are apparently affected by the shallow subduction component.

Recent exploration in this region with submersible vehicles has discovered four active hydrothermal vent sites of the Yamanaka, Snail, Arhcean, and Pika sites (Urabe et al. 2004). Two of them (Yamanaka and Snail sites) are situated on the spreading axis, whereas the other two (Archaean and Pika sites) are located on off-axis seamounts, which are on the southeast of the spreading center region (Fig. 41.1). 


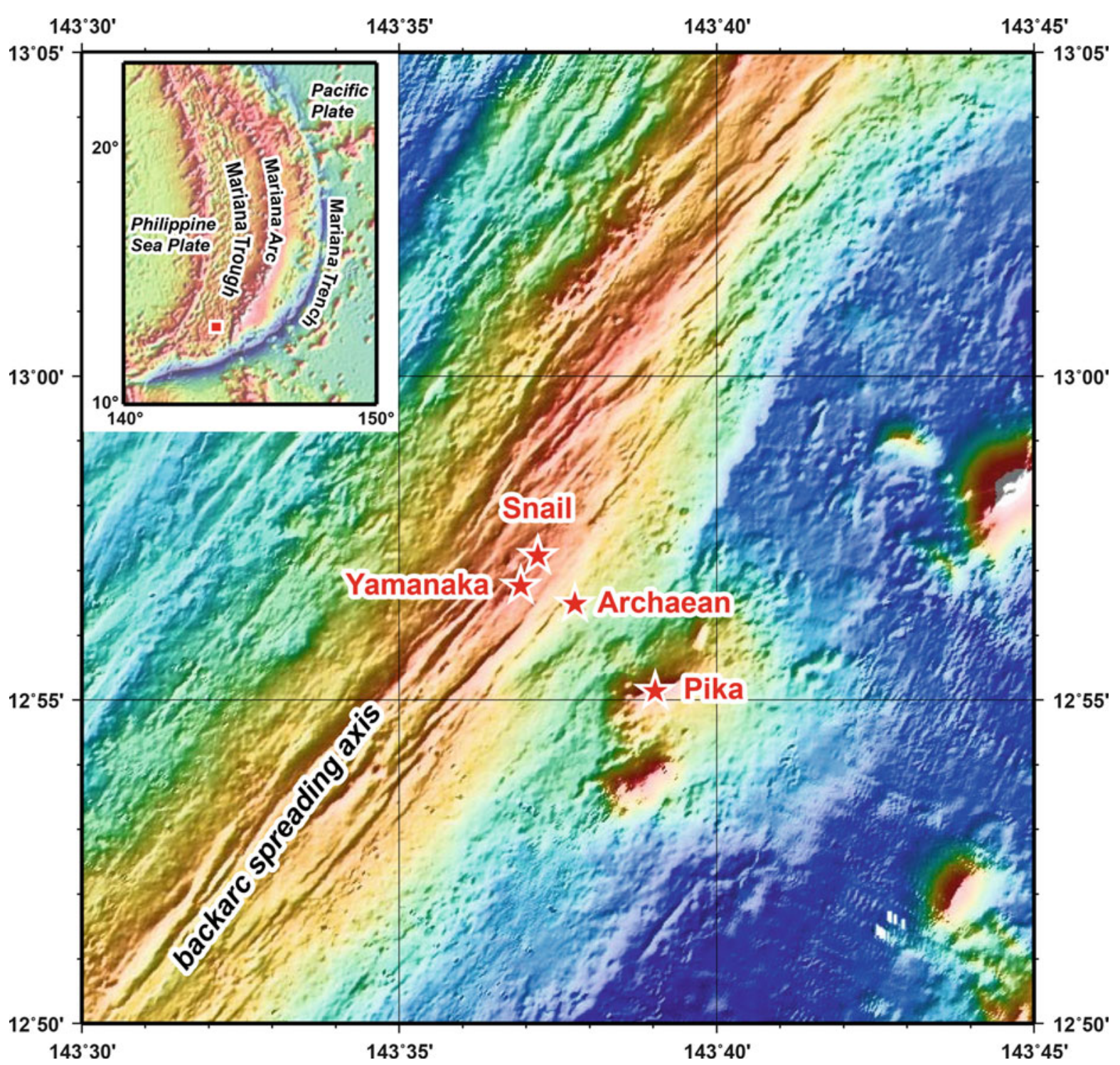

Fig. 41.1 Bathymetric map showing the locations of the four hydrothermal vent sites (the Snail, Yamanaka, Archaean, and Pika sites) at the Southern Mariana Trough

\subsection{Site Description}

From 14 June to 23 June 2010, we conducted TAIGA10M cruise by R/V Hakurei-Maru No.2 at the SMT. During the cruise, we performed seafloor drilling with 12 holes at the four hydrothermal vent sites (Yamanaka, Snail, Archaean, and Pika sites) using the Benthic Multi-coring System (BMS); one hole at the Snail site (BMS-01), one hole at the Yamanaka site (BMS-04), seven holes at the Archaean site (BMS-02, 03, 06A, B, C, D, 07), and three holes at the Pika site (BMS-05, 08, 09) (Fig. 41.2). Summary of the BMS sampling during TAIGA10M cruise is given in Table 41.1.
Site BMS-01 This site is located at the Snail hydrothermal site. The target of this drilling was to collect sulfides and basement rocks. We installed BMS right on the axis near the Marker 24 site, where pillow lava was extensively exposed without sediment cover. Drilling was smooth and the drilling speed was constant. After the drilling, fluid venting was observed from the borehole.

Site BMS-02 This site is located at the Archaean hydrothermal site. At this site, we originally planned to recover volcanic rocks beneath the hydrothermal site. The drilling site was sedimented with talus of sulfide blocks, from upslope, covered with about $7 \mathrm{~cm}$ of red-colored, soft 

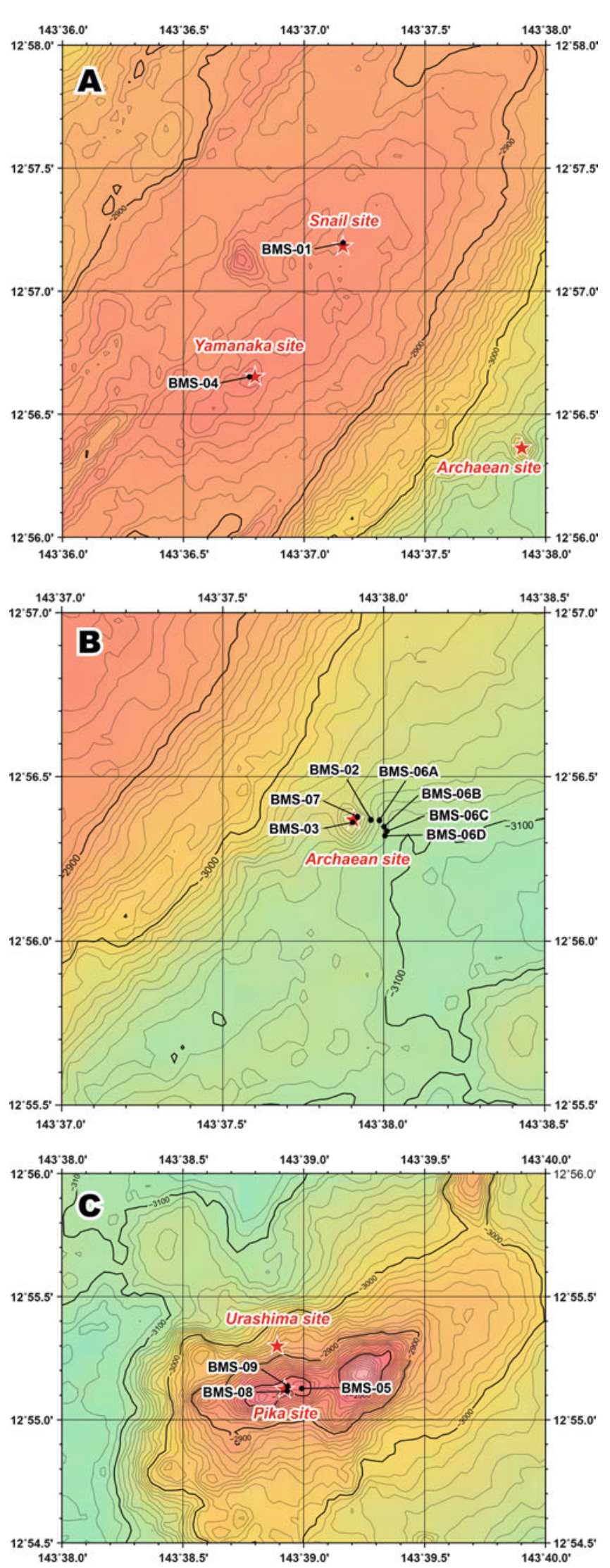

Fig. 41.2 Positions of the BMS drilling at and near the (a) Snail, Yamanaka, (b) Archaean, and (c) Pika hydrothermal sites. Note that newly discovered the Urashima hydrothermal site (Nakamura et al. 2013) located at northern part of the Pika site is also shown in (c) sediment. Because the bit was clogged at depth of $167 \mathrm{~cm}$, we quit drilling at that depth.

Site BMS-03 This site is also located at the Archaean hydrothermal site. We spent a long time searching for basement volcanic rocks, but the seamount hosting the Archaean site is entirely covered by talus of sulfide blocks here as well,. The area where we installed the BMS is similar to that of BMS- 02 with $20 \mathrm{~cm}$ of red-colored soft sediments covering the sulfide blocks.

Site BMS-04 This site is located at the Yamanaka hydrothermal site. At this site, we planned to sample fresh basement rocks. As at the Snail site, pillow lava was extensively exposed without sediment cover. After the drilling, we noticed that hydrothermal fluid was shimmering from the borehole.

Site BMS-05 This site is located at the Pika hydrothermal site. Targets of this drilling were materials from an inactive sulfide mound and underlying basement rocks. We drilled at the top of the sulfide mound. It has a diameter of more than $5 \mathrm{~m}$ and is topped by many small dead chimneys of about $50 \mathrm{~cm}$ in height.

Sites BMS-06A to D These sites are located around the Archaean hydrothermal site. In a series of drill holes from 06A to 06D, we intended to recover fresh basement rocks from the site for the first time. At the top of seamount hosting Archaean site, sulfide chimneys and mounds are extensively exposed, whereas pillow and sheet flow lavas, covered by reddish brown sediments, lie at the base of the seamount. Drilling was quite successful and we recovered fresh sulfide blocks (06A), pillow lava (06B, C) and sheet flow lava (06D).

Site BMS-07 This site is also located at the Archaean hydrothermal site. The target of this drilling was to recover fresh sulfide ores. The BMS was installed on top of a hill that is entirely covered by sulfide chimneys or their broken equivalents. There were also a few dead chimneys around the drilling site.

Site BMS-08 This site is located at the Pika hydrothermal site. The purpose of the drilling was to recover high temperature fluid and fresh sulfide ore. The BMS was set on the top of a small mound that turned out to be not a sulfide mound, but a pillow lava mound. After drilling, however, weak fluid venting was observed from the borehole.

Site BMS-09 This site is also located at the Pika hydrothermal site. The target of this drilling was high-temperature hydrothermal fluid. The BMS was installed near a clear smoker chimney. Drilling was done on the edge of a sulfide mound where we observed many slender chimneys (some of them were still active). Unfortunately, however, no fluid venting (not even a low-temperature one) was observed after the drilling. 
Table 41.1 Summary of core sampling operations during TAIGA10M cuirse

\begin{tabular}{|c|c|c|c|c|c|c|c|c|c|}
\hline \multirow[b]{2}{*}{ Drilling site } & \multirow[b]{2}{*}{ Date } & \multirow[b]{2}{*}{ Device } & \multicolumn{2}{|l|}{ Position $^{a}$} & \multirow{2}{*}{$\begin{array}{l}\text { Water } \\
\text { depth }^{\mathrm{b}} \\
(\mathrm{m})\end{array}$} & \multirow{2}{*}{$\begin{array}{l}\text { Drilled } \\
\text { depth } \\
(\mathrm{cm})\end{array}$} & \multirow{2}{*}{$\begin{array}{l}\text { Core } \\
\text { length } \\
(\mathrm{cm})\end{array}$} & \multirow{2}{*}{$\begin{array}{l}\text { Core } \\
\text { recovery } \\
(\%)\end{array}$} & \multirow{2}{*}{$\begin{array}{l}\text { Casing } \\
\text { pipe }\end{array}$} \\
\hline & & & Latitude & Longitude & & & & & \\
\hline \multicolumn{10}{|l|}{ Snail site } \\
\hline TAIGA10-BMS-01 & $6 / 15 / 2010$ & BMS & $12^{\circ} 57.1957^{\prime} \mathrm{N}$ & $143^{\circ} 37.1616^{\prime} \mathrm{E}$ & $2,878.7$ & 477 & 458 & 96 & Yes \\
\hline \multicolumn{10}{|l|}{ Yamanaka site } \\
\hline TAIGA10-BMS-04 & $6 / 17 / 2010$ & BMS & $12^{\circ} 56.6515^{\prime} \mathrm{N}$ & $143^{\circ} 36.7749^{\prime} \mathrm{E}$ & $2,843.1$ & 709 & 435 & 61 & No \\
\hline \multicolumn{10}{|l|}{ Archaean site } \\
\hline TAIGA10-BMS-02 & $6 / 16 / 2010$ & BMS & $12^{\circ} 56.3696^{\prime} \mathrm{N}$ & $143^{\circ} 37.9599^{\prime} \mathrm{E}$ & $3,073.5$ & 167 & 92 & 55 & No \\
\hline TAIGA10-BMS-03 & $6 / 16 / 2010$ & BMS & $12^{\circ} 56.3627^{\prime} \mathrm{N}$ & $143^{\circ} 37.9036^{\prime} \mathrm{E}$ & $3,021.7$ & 330 & 252 & 76 & No \\
\hline TAIGA10-BMS-06A & $6 / 19 / 2010$ & BMS & $12^{\circ} 56.3678^{\prime} \mathrm{N}$ & $143^{\circ} 37.9867^{\prime} \mathrm{E}$ & $3,101.4$ & 112 & 53 & 47 & No \\
\hline TAIGA10-BMS-06B & $6 / 19 / 2010$ & BMS & $12^{\circ} 56.3494^{\prime} \mathrm{N}$ & $143^{\circ} 38.0008^{\prime} \mathrm{E}$ & $3,107.0$ & 243 & 108 & 44 & No \\
\hline TAIGA10-BMS-06C & $6 / 19 / 2010$ & BMS & $12^{\circ} 56.3358^{\prime} \mathrm{N}$ & $143^{\circ} 38.0094^{\prime} \mathrm{E}$ & $3,107.7$ & 138 & 77 & 56 & No \\
\hline TAIGA10-BMS-06D & $6 / 19 / 2010$ & BMS & $12^{\circ} 56.3223^{\prime} \mathrm{N}$ & $143^{\circ} 38.0043^{\prime} \mathrm{E}$ & $3,114.2$ & 205 & 75 & 37 & No \\
\hline TAIGA10-BMS-07 & $6 / 20 / 2010$ & BMS & $12^{\circ} 56.3783^{\prime} \mathrm{N}$ & $143^{\circ} 37.9187^{\prime} \mathrm{E}$ & $3,007.6$ & 362 & 173 & 48 & No \\
\hline \multicolumn{10}{|l|}{ Pika site } \\
\hline TAIGA10-BMS-05 & $6 / 18 / 2010$ & BMS & $12^{\circ} 55.1271^{\prime} \mathrm{N}$ & $143^{\circ} 38.9919^{\prime} \mathrm{E}$ & $2,820.7$ & 776 & 356 & 46 & Yes \\
\hline TAIGA10-BMS-08 & $6 / 21 / 2010$ & BMS & $12^{\circ} 55.1153^{\prime} \mathrm{N}$ & $143^{\circ} 38.9329^{\prime} \mathrm{E}$ & $2,806.1$ & 263 & 195 & 74 & Yes \\
\hline TAIGA10-BMS-09 & $6 / 21 / 2010$ & BMS & $12^{\circ} 55.1369^{\prime} \mathrm{N}$ & $143^{\circ} 38.9334^{\prime} \mathrm{E}$ & $2,804.3$ & 425 & 292 & 69 & No \\
\hline
\end{tabular}

${ }^{\mathrm{a}}$ Position of the drilling site was determined based on GPS data of the ship

${ }^{b}$ Water depth of the drilling site was determined based on MBES data

\subsection{Core Description}

Descriptions of the 12 cores drilled from the four hydrothermal vent sites are summarized in Fig. 41.3. In this section, we describe petrological characteristics of the 38 core sections from the 12 holes.

\subsubsection{Site BMS-01}

Core BMS-01-01 section A Basalt to basaltic andesite pillow fragments were recovered in this core section. They are aphyric, angular and have alteration coatings on fracture surfaces. The core pieces have a vitric groundmass and contain vesicles that are elongate and medium to large in size. In the lower part of the core, a second pillow was penetrated. This is also aphyric, with mainly very small vesicles that define trails, suggesting direction of movement of the lava. Larger vesicles are lined with alteration rims of dark reddish brown.

Core BMS-01-01 section B Basalt to basaltic andesite pillow interiors (no glass margins in this section) were recovered. The rock in this section is also aphyric, with very small vesicles, similar to the previous section. There are many vesicle trails throughout the section. In the upper part of this section, fracture surfaces are coated with yellow and gray alteration products (maybe clay minerals). In the lower part, the alteration on fracture surfaces is mainly gray and/or yellowish, but also contains streaks of orange/red/brown.

Core BMS-01-02 section A Basalt to basaltic andesite pillow lava pieces were recovered. The rock is aphyric, with very small vesicles, similar to the previous section. Many vesicle trails are also observed throughout the section. Larger vesicles have a thin lining of a gray alteration product, and the fracture surface has a yellow/orange alteration coating.

Core BMS-01-02 section B Basalt to basaltic andesite pillow interior was recovered. The rock is aphyric, with very small vesicles, similar to the previous section, but occasional large vesicles also occur. In the upper part of this section, there is a yellow and gray alteration coating on fracture surfaces with some brown alteration. In the lower part of this section, fracture surfaces have gray alteration with some streaks of brown and some scattered patches of yellow.

Core BMS-01-02 section C Basalt to basaltic andesite pillow interior was recovered. The rock is aphyric, with very small vesicles, similar to the previous section, but has occasional large vesicles, which increase in number downsection. Some pieces in the middle part of the section are likely the glassy margin of a large pillow. Vesicle trails lie at a high angle to the core. Fracture surfaces are coated with yellow and gray alteration products. 


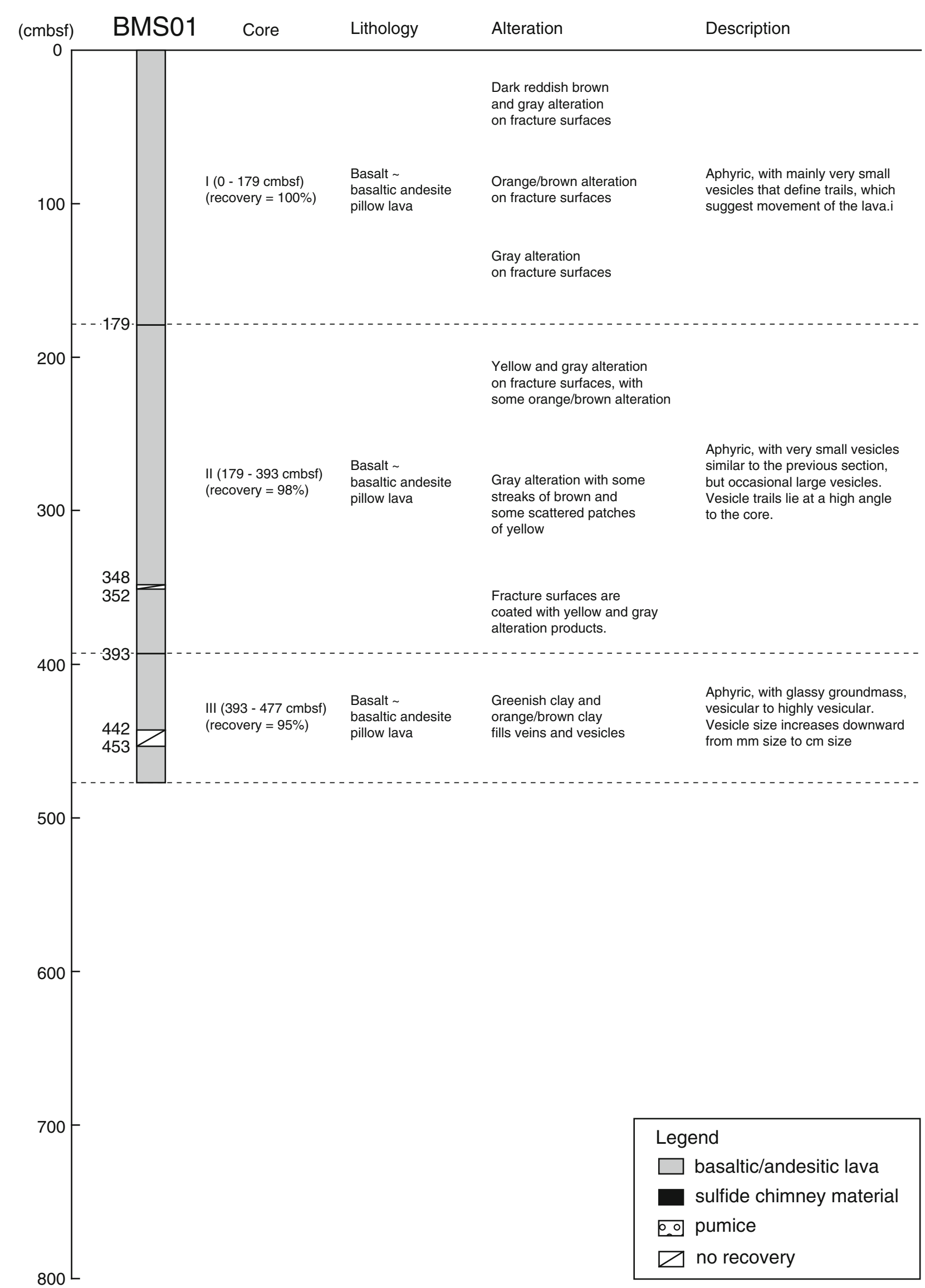

Fig. 41.3 Visual core description for BMS cores drilled from 12 sites at the Snail, Yamanaka, Archaean, and Pika hydrothermal vent sites 


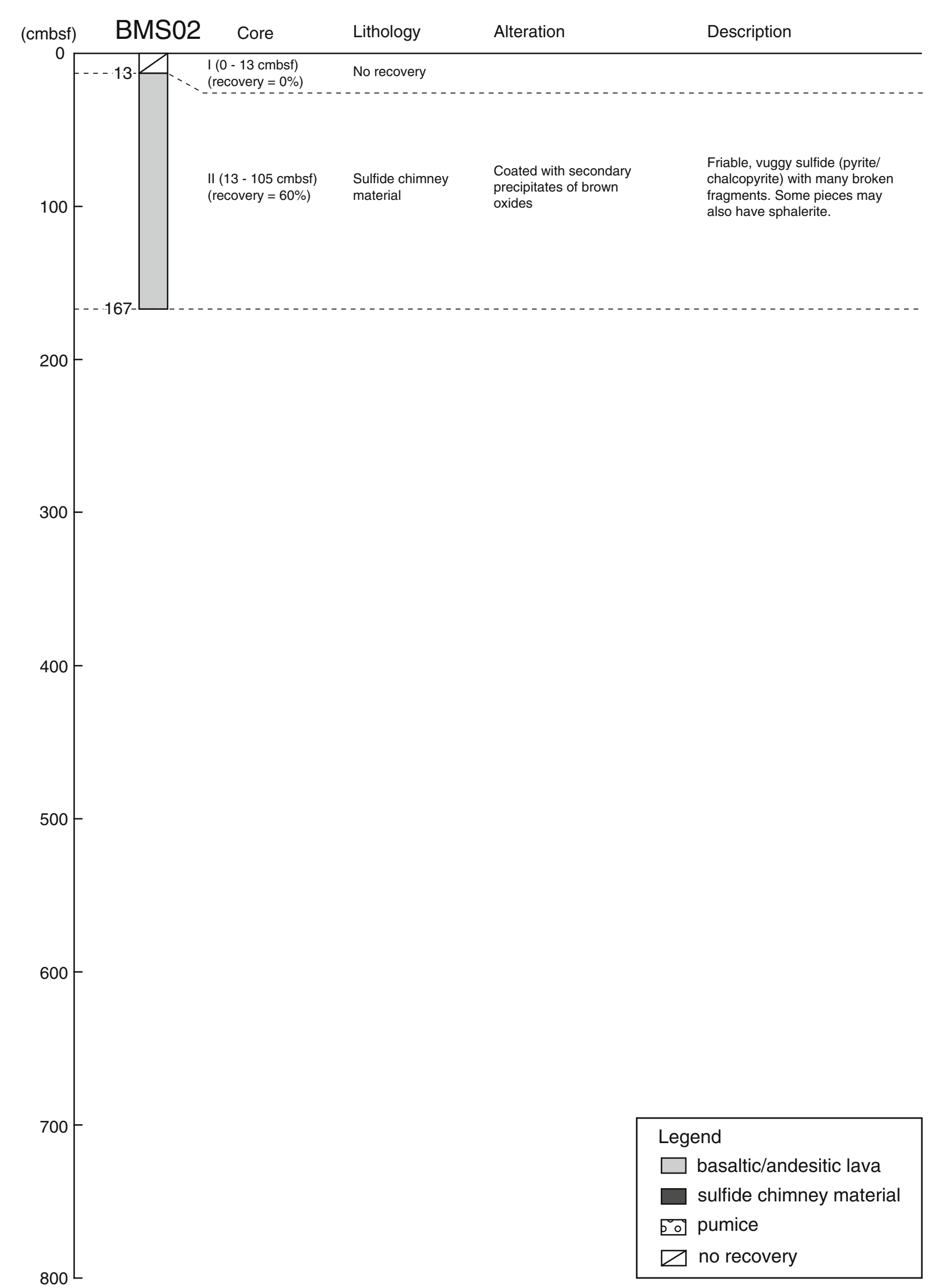

Fig. 41.3 (continued) 


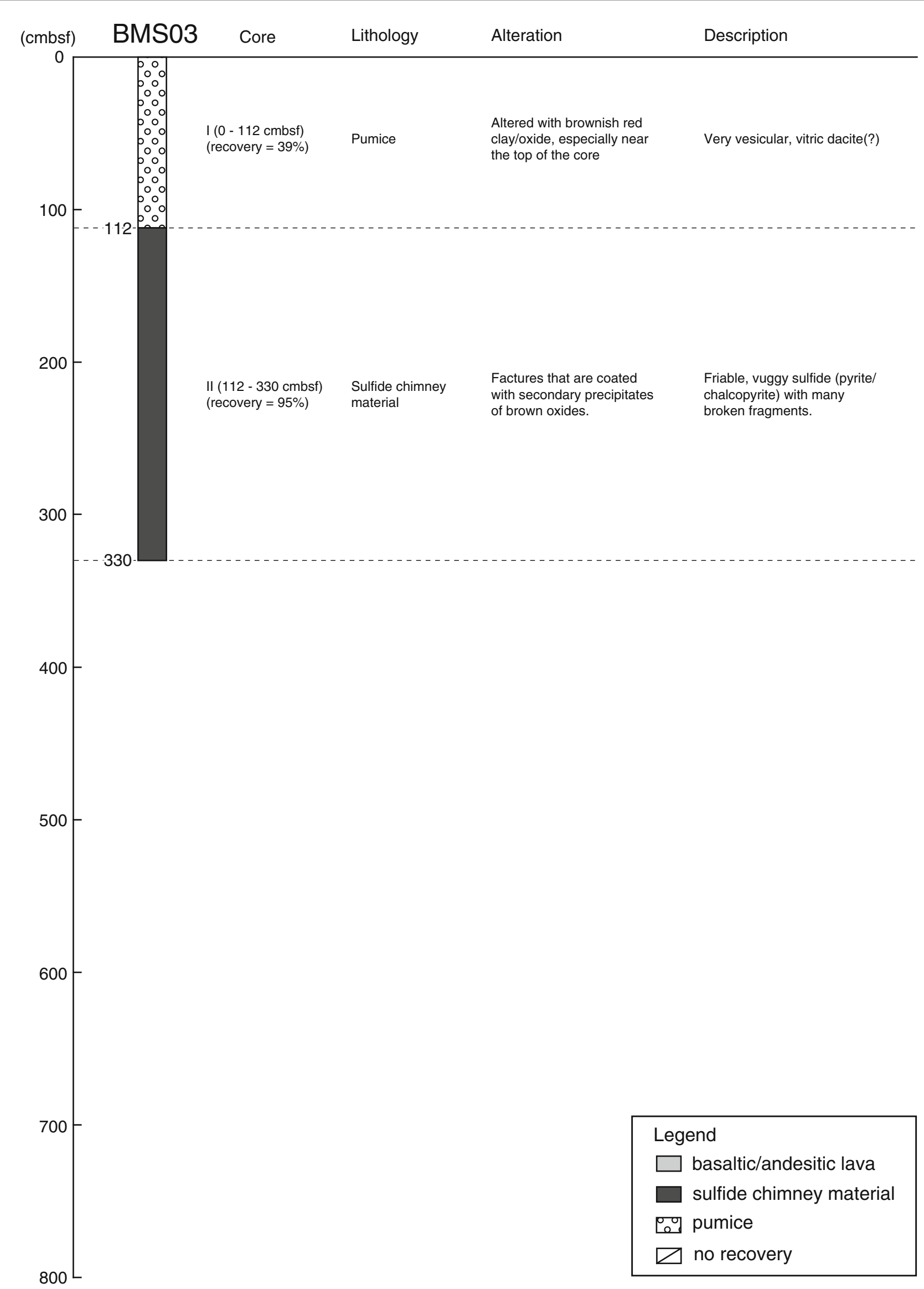

Fig. 41.3 (continued) 


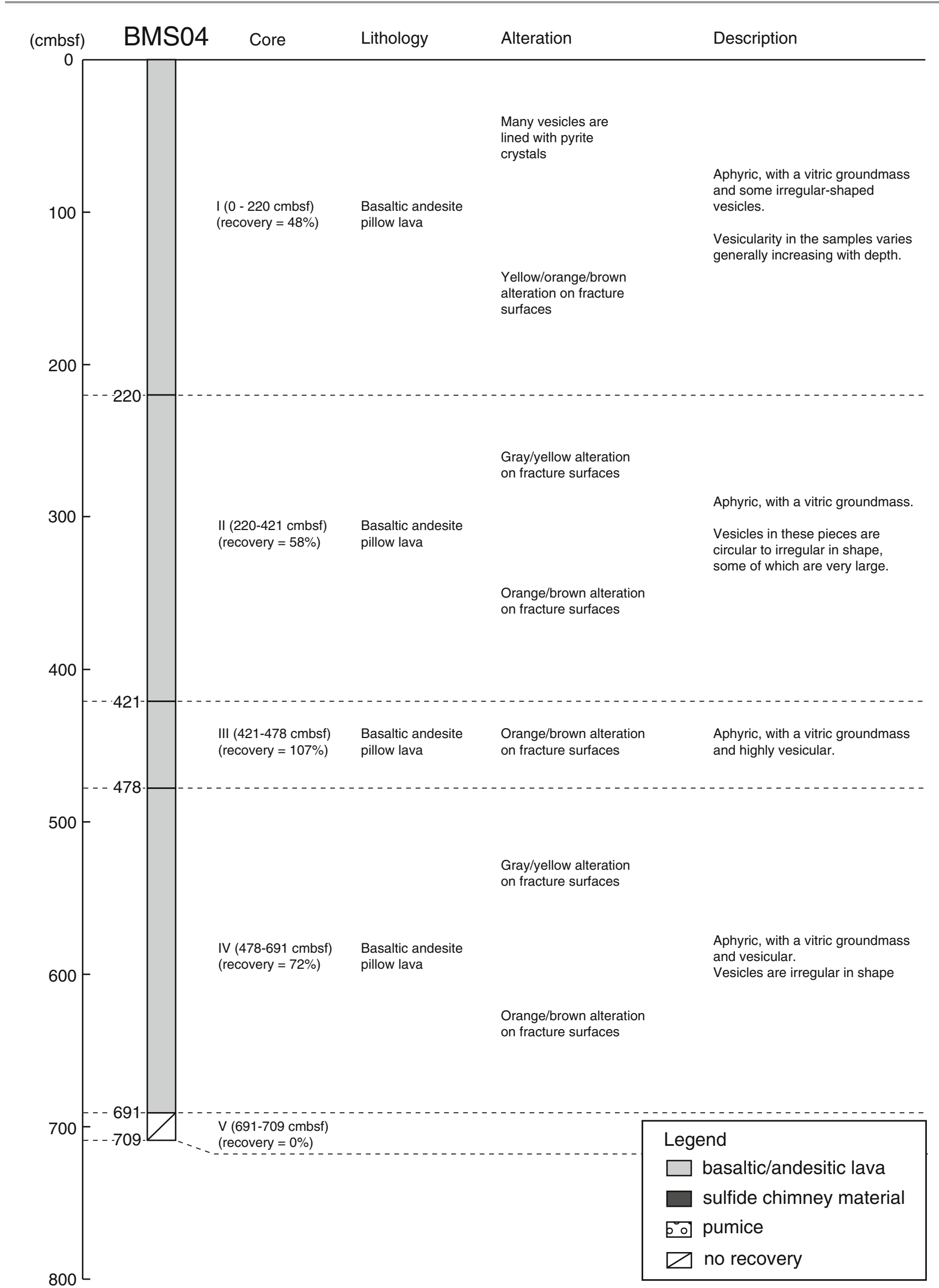

Fig. 41.3 (continued) 


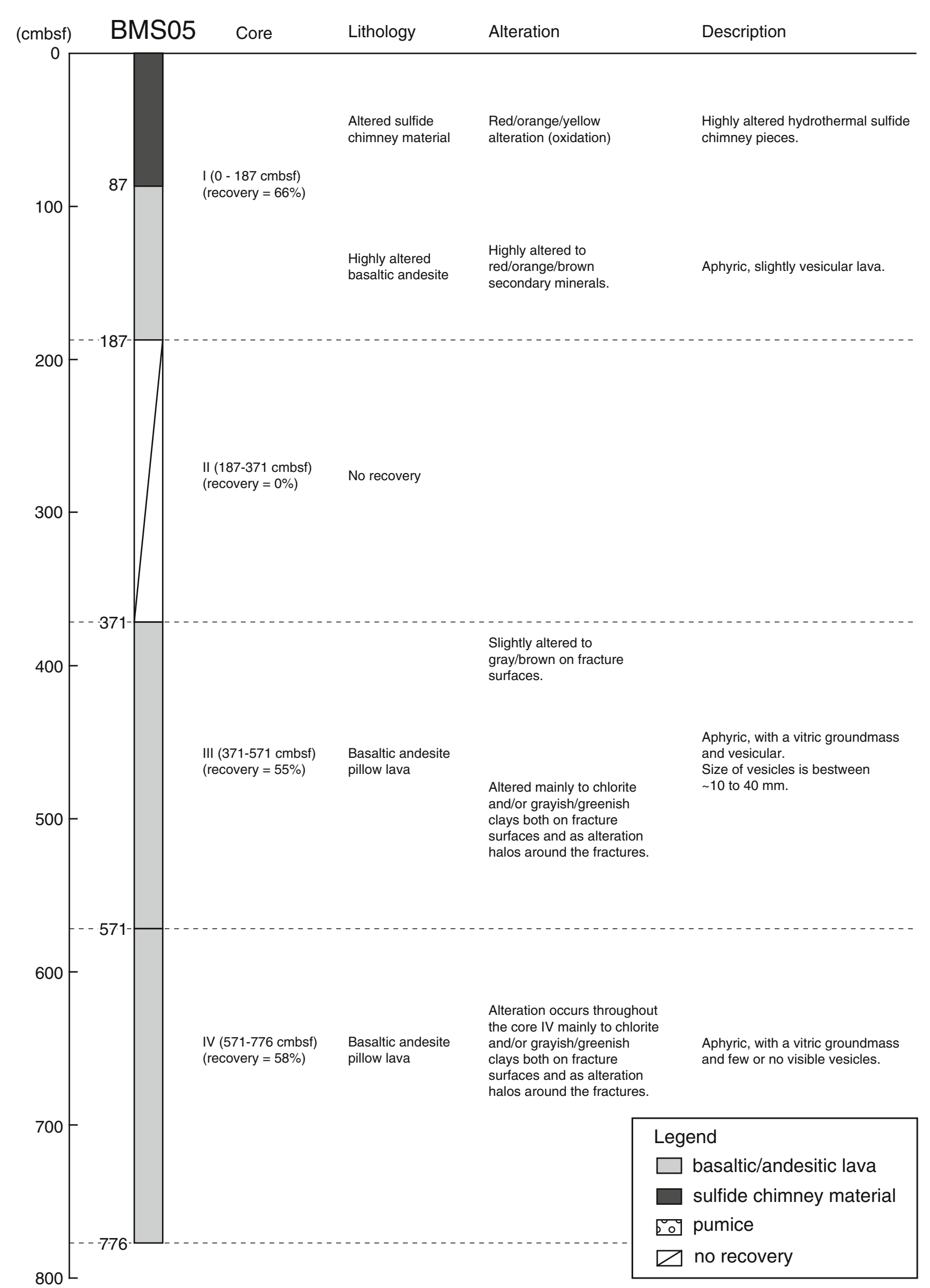

Fig. 41.3 (continued) 


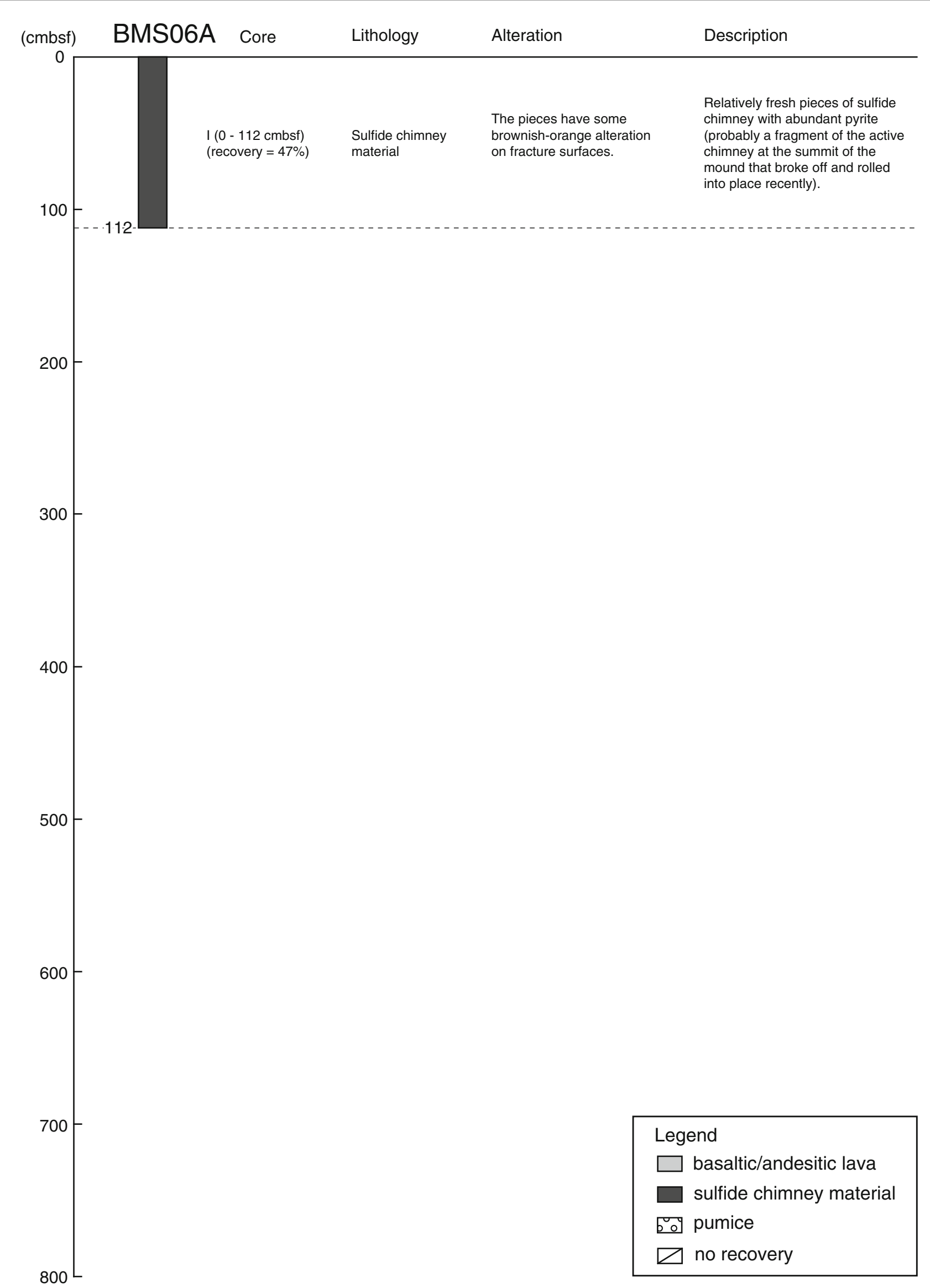

Fig. 41.3 (continued) 


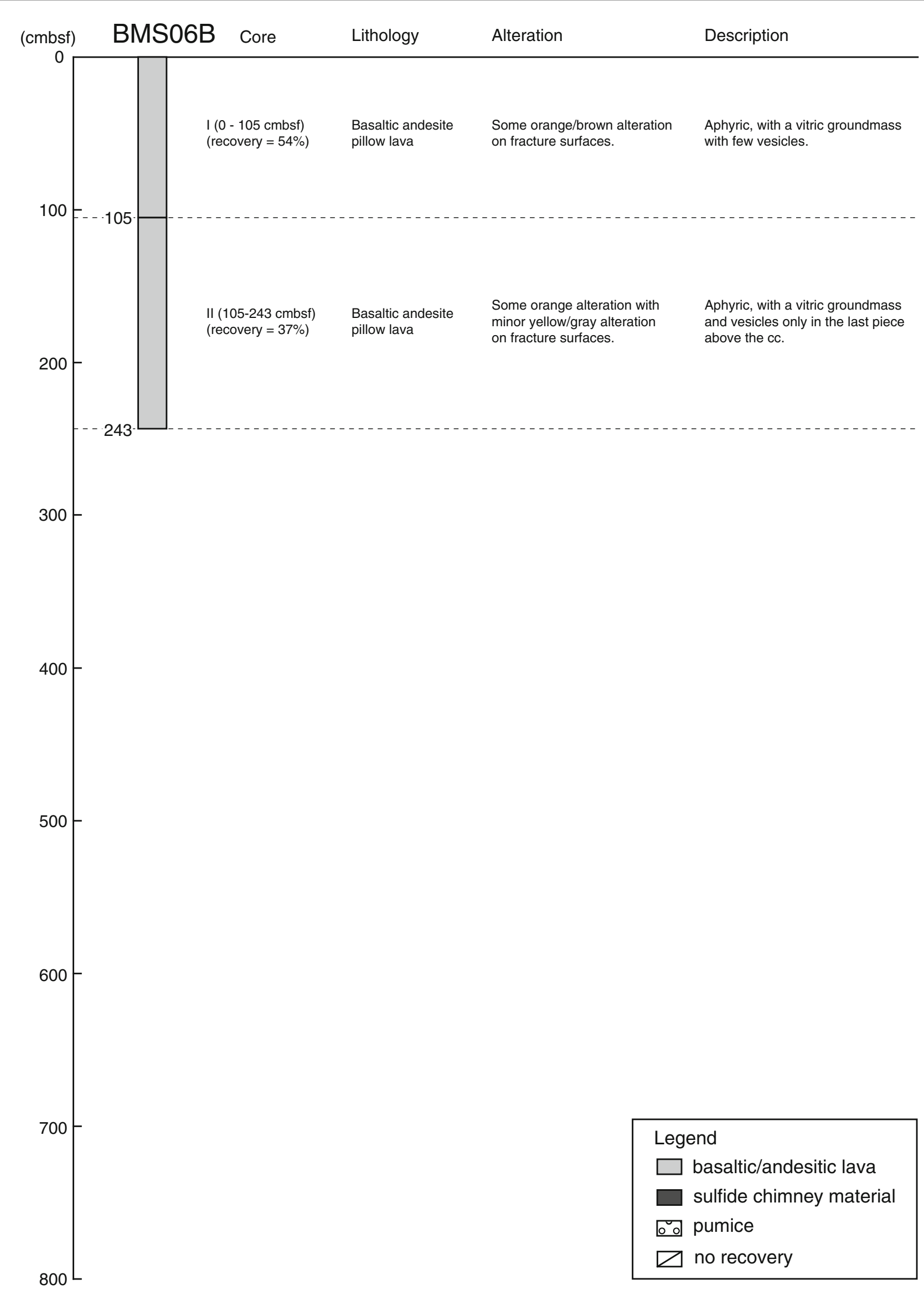

Fig. 41.3 (continued) 


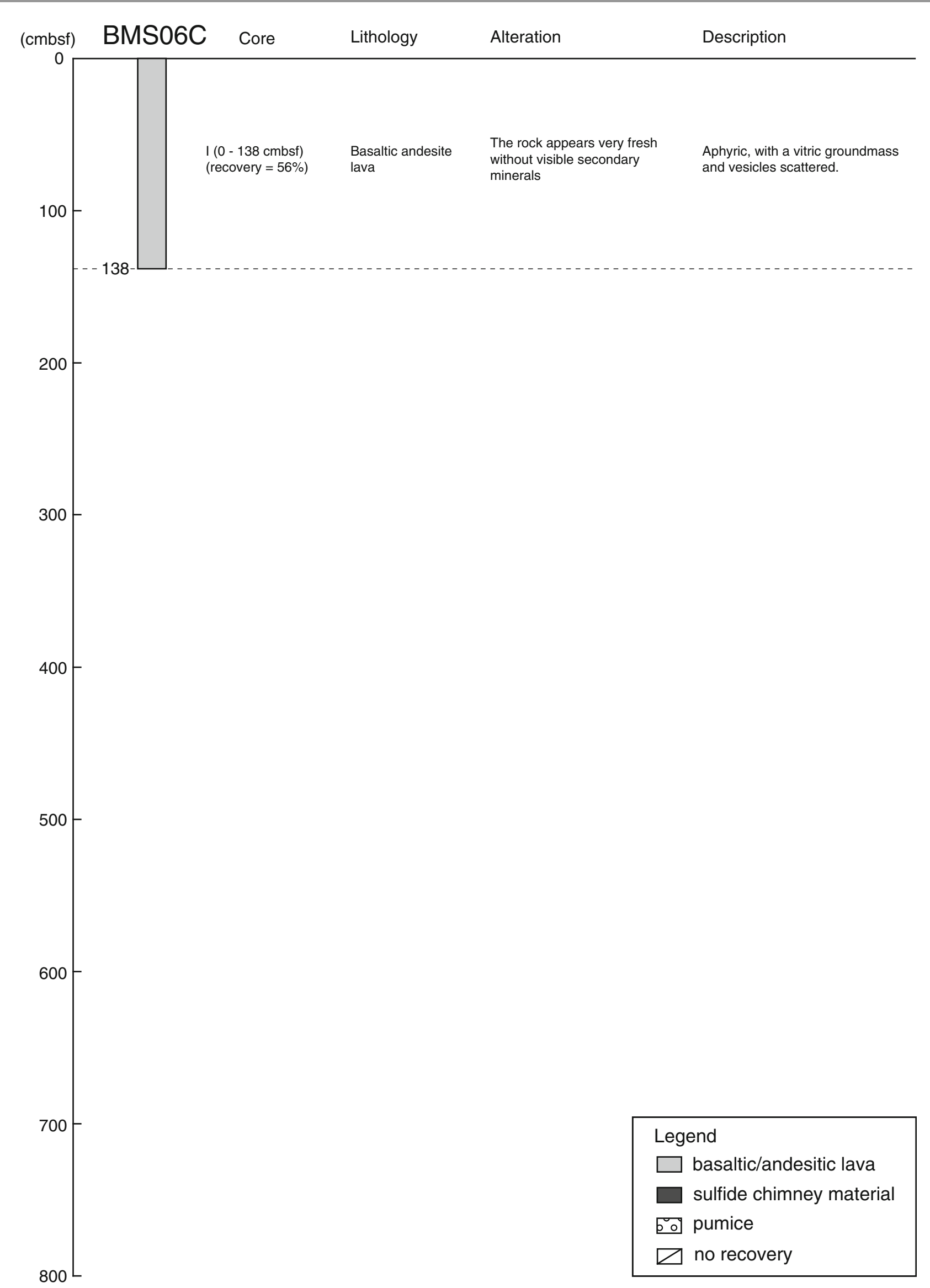

Fig. 41.3 (continued) 


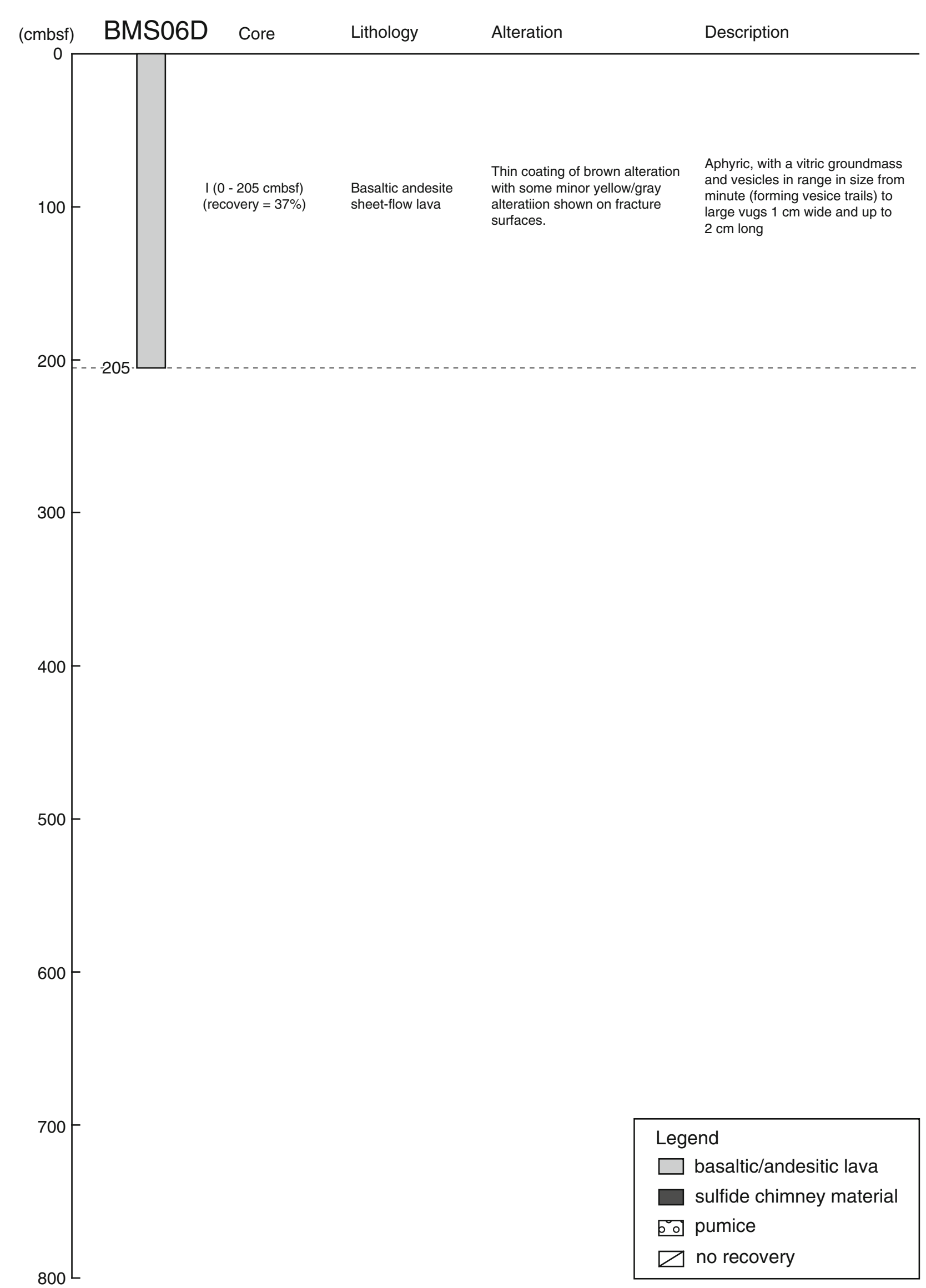

Fig. 41.3 (continued) 


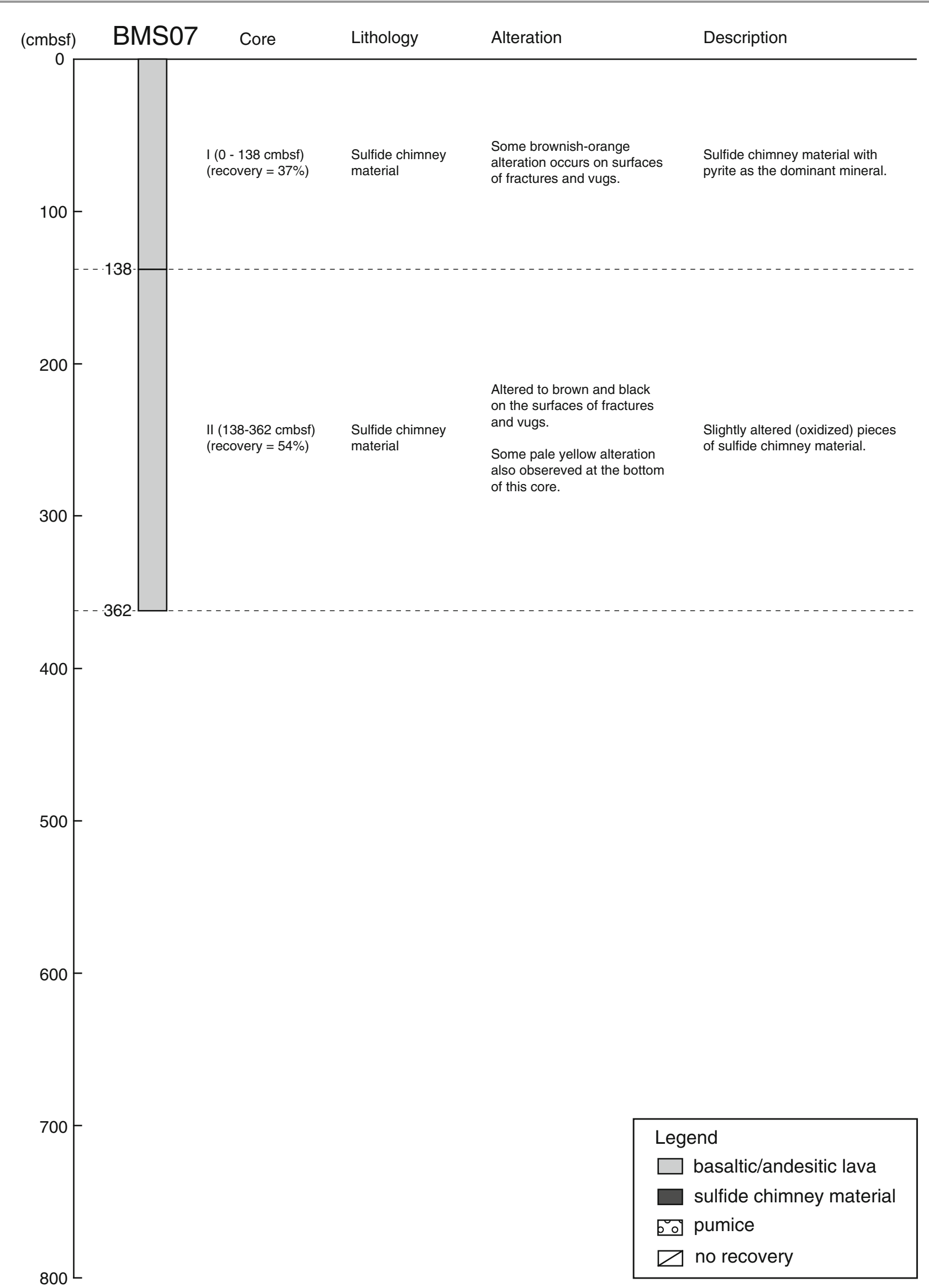

Fig. 41.3 (continued) 


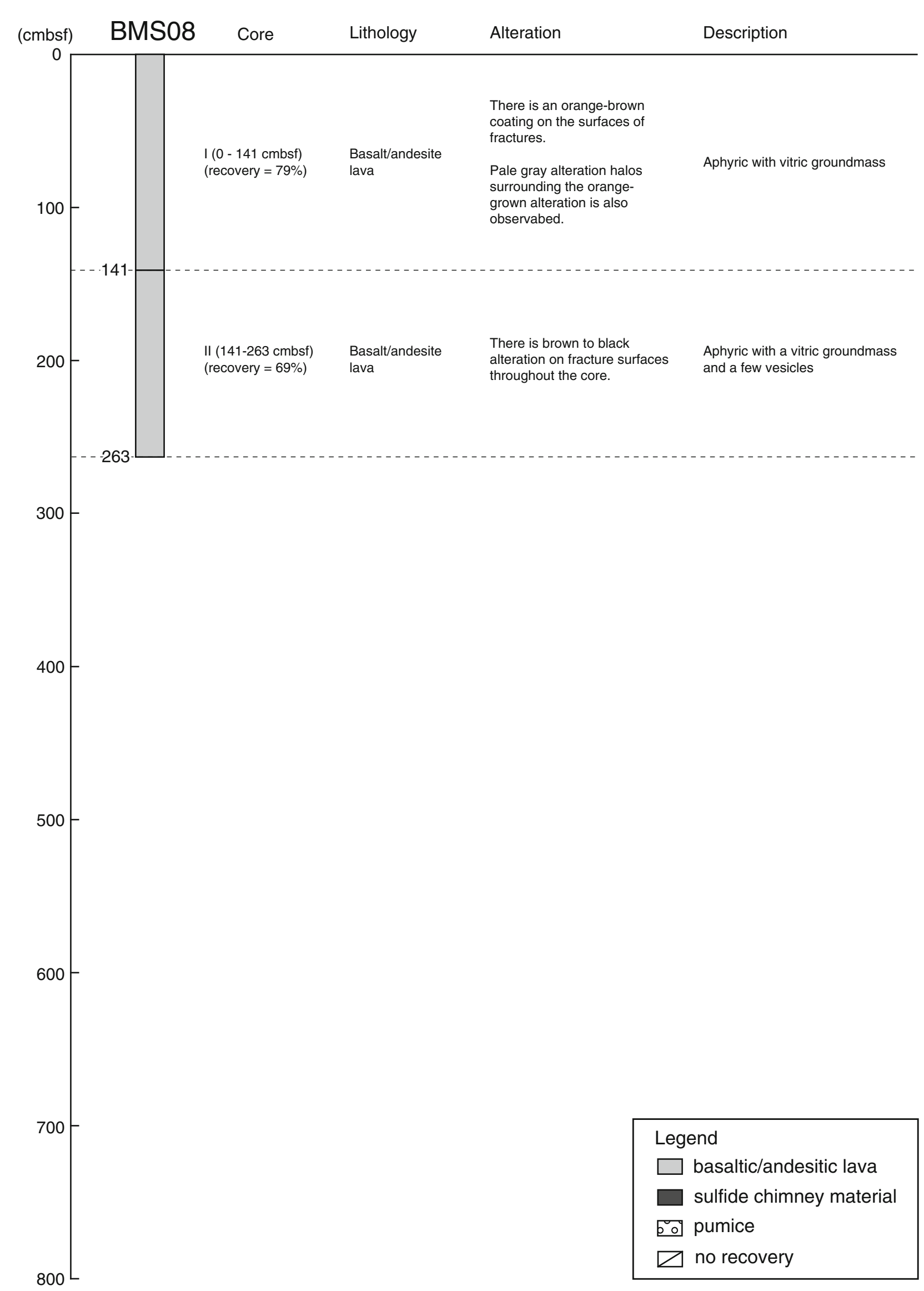

Fig. 41.3 (continued) 


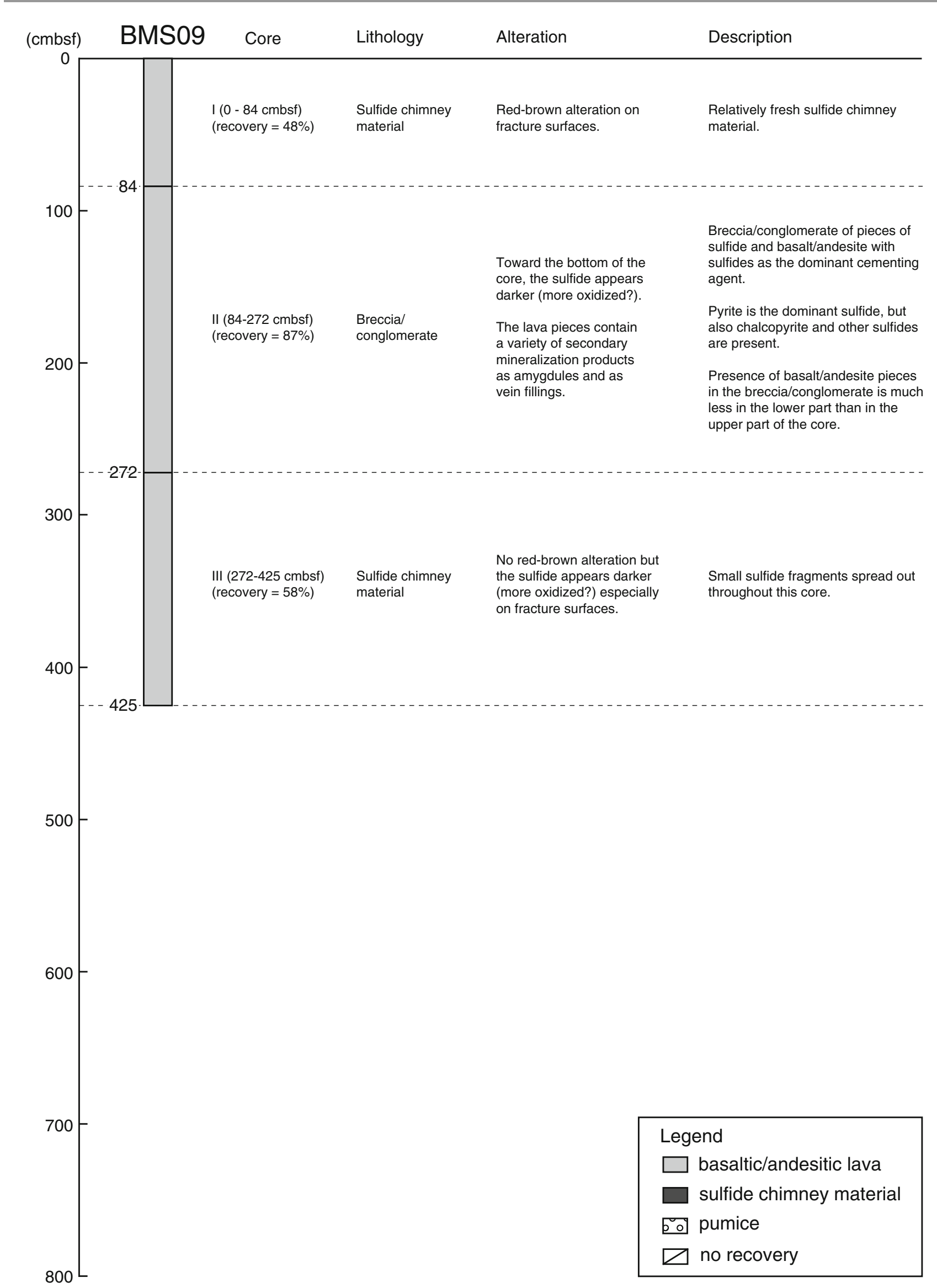

Fig. 41.3 (continued) 
Core BMS-01-03 section A Basalt to basaltic andesite pillow lava pieces were recovered. The rock is aphyric, with glassy groundmass and is vesicular. Vesicle size increases downward from mm-size to $\mathrm{cm}$-size. The vesicles are lined with yellowish and orange-brown clay (?) minerals with/without goethite, and greenish clay and/or orangebrown clay fill veins.

\subsubsection{Site BMS-02}

Core BMS-02-01 No sample was recovered in this core.

Core BMS-02-02 This core comprises sulfide chimney material, a friable and vuggy sulfide precipitate mass (pyrite/ chalcopyrite) with many broken fragments. Some pieces in the core were recovered intact, but most have fractures that are coated with secondary precipitates of brown clays (?) or oxides. In the lower part of the section, some pieces may have sphalerite in addition to pyrite/chalcopyrite.

\subsubsection{Site BMS-03}

Core BMS-03-01 Several pieces of pumice were recovered. The rocks are very vesicular with vitric groundmass, and are likely dacitic in composition and altered (especially near the top of the core) with brownish red clay/oxide.

Core BMS-03-02 section A Only a few small fragments of sulfide chimney material were recovered. Those are friable and vuggy, composed mainly of pyrite and chalcopyrite.

Core BMS-03-02 section B Sulfide chimney material, which is friable, vuggy and composed mainly of pyrite/ chalcopyrite, was recovered. Some pieces are very long (up to $\sim 35 \mathrm{~cm}$ long), but also there are many broken fragments in the core. Several pieces in core that were recovered intact also have fractures that are coated with secondary precipitates of brown clays(?) or oxides.

Core BMS-03-02 section C Sulfide chimney material similar to that recovered in the previous section was recovered in this section. Some fragments are broken. Fracture surfaces on the core do have some alteration products.

\subsubsection{Site BMS-04}

Core BMS-04-01 Basalt to andesite pillow lava pieces were recovered in this section. The rocks are aphyric with a vitric groundmass, containing vesicles that have linings that contain tiny pyrite crystals. The rocks are particularly glassy at the top of the section. The vesicularity in the samples varies with depth in the section, larger round vesicles occur at the middle part and irregular vesicles occur at the lower part of the section. Alteration varies in color down-section. There is a gray lining to a vesicle and a fracture coating of yellow to brown in the upper part of the section. At the lower part, the coatings are orange/brown. A yellow to orange/brown alteration occurs at the bottom of the section.

Core BMS-04-02 section A Basalt to andesite pillow lava was recovered. The rock is aphyric, with a vitric groundmass and is vesicular throughout. Vesicles in these pieces are circular to irregular in shape and some of them are very large. Glassy pieces occur in the rubble at the top of the section. Alteration on fracture surfaces is gray/yellow.

Core BMS-04-02 section B Basalt to andesite pillow lava pieces were recovered. The rocks are aphyric, with a vitric groundmass. Vesicles are sparse at the upper and middle parts of the section, whereas at the lower part the rock is much more vesicular. This vesicularity change suggests two pillows were penetrated. Fracture surfaces at the upper and middle part of the section are altered to gray/brown, whereas those in the lower part have generally orange/brown alteration coating.

Core BMS-04-03 This core comprises basalt to andesite pillow lava, which is aphyric with a vitric groundmass and highly vesicular. The small pieces at the top of the section are glassy and probably represent the margin of a pillow. Alteration on fracture surfaces is mainly orange, and vesicles show yellow/orange or gray/yellow alteration.

Core BMS-04-04 section A Basalt to andesite pillow lava was recovered. The rock is aphyric, with a vitric groundmass, and is vesicular. Vesicles in these pieces are irregular in shape. There is glass in the rubble at the top of the section. Alteration on fracture surfaces is gray/yellow or orange.

Core BMS-04-04 section B Basalt to andesite pillow lava was recovered. The rock is aphyric, with a vitric groundmass and vesicles that are scattered and increase in number downsection. Compared to the upper part of the section, there are more vesicles and they are more irregular in shape in the lower part, suggesting that two pillows were penetrated. Glass margins are observed on some pieces. In the upper part, alteration is orange or orange/brown. On the other hand, in the lower part, fracture surfaces have a brown or gray coating. 


\subsubsection{Site BMS-05}

Core BMS-05-01 section A Sulfide chimney material, which was highly altered to black/brown oxide, was recovered.

Core BMS-05-01 section B Highly oxidized sulfide chimney material and basalt to andesite pillow were recovered. The chimney material is highly altered with red/orange/ yellow/black contorted precipitates. In addition to the strong oxidation, this may also have undergone silicification. In the lower part of the core, there are two pieces of highly altered (oxidized) basalt to andesite pillow lava. The rock is aphyric, slightly vesicular lava that has been altered to red/orange/ brown alteration products.

Core BMS-05-02 No sample was recovered in this core.

Core BMS-05-03 section A Basalt to andesite pillow lava, which is aphyric with a vitric groundmass and vesicular, was recovered. There is a glass margin on the top pieces of this section. Also some red/brown fragments (likely from the section above) occur among the top few pieces of the section. In contrast to the above sections, only some alteration to gray-brown on fracture surfaces is observed in this section.

Core BMS-05-03 section B Basalt to andesite pillow lava was recovered. The rock is aphyric, with a vitric groundmass and has few vesicles at the upper part of the section. Alteration occurs throughout the section, mainly to chlorite and/ or greenish clays, both on fracture surfaces and as alteration halos around the fractures. A coating of chlorite is observed in some pieces.

Core BMS-05-04 section A Basalt to andesite pillow lava was recovered. The rock is aphyric, with a vitric groundmass and few vesicles. Alteration similar to the previous section occurs throughout the section. Some pieces have thick alteration halos $(\sim 1 \mathrm{~cm}$ thick) extending from the fracture surface.

Core BMS-05-04 section B Basalt to andesite pillow lava that is aphyric, with a vitric groundmass and few or no visible vesicles, was recovered. Vesicules occurs only at the lowermost part of the section. A glass margin occurs at the upper part of the section and there are a few small glass fragments in the lower part. The glass intervals suggest two to three pillows were penetrated. Alteration occurs throughout the section mainly to chlorite and/or greenish clays, both on fracture faces and as alteration halos around the fractures.

\subsubsection{Site BMS-06A}

Core BMS-06A Relatively fresh pieces of sulfide chimney with abundant pyrite (probably a fragment of the active chimney at the summit of the mound that broke off and rolled into place recently) were recovered. The pieces have vugs of various sizes. Some brownish-orange alteration coatings are observed on fracture surfaces.

\subsubsection{Site BMS-06B}

Core BMS-06B-01 Basaltic andesite pillow lava was recovered. The rock is aphyric, with a vitric groundmass and few vesicles. Some orange/brown alteration occurs especially at the middle part of the section.

Core BMS-06B-02 Basaltic andesite pillow lava, which is aphyric, with a vitric groundmass and vesicles, was recovered. There are glass fragments in the top part of the section and a $\sim 1 \mathrm{~cm}$ thick glass margin on top of the top piece of this section. There is some orange alteration coatings (with some minor yellow and gray) on fracture surfaces of the pieces only at the lower part of the section.

\subsubsection{Site BMS-06C}

Core BMS-06C Basaltic andesite pillow lava was recovered. The rock is aphyric, with a vitric groundmass. A rubble of small fragmets from the top of the section is very glassy. Vesicles are scattered, but are especially common in the middle part of the section. This more vesicular rock contains vertical trails of tiny vesicles. The rock appears very fresh, containing no visible secondary minerals.

\subsubsection{Site BMS-06D}

Core BMS-06D Basaltic andesite sheet-flow lava was recovered. The rock is aphyric, with a vitric groundmass and vesicles that range in size from minute (forming vesicle trails) to large vugs, $1 \mathrm{~cm}$ wide and up to $2 \mathrm{~cm}$ long. Some pieces from middle and bottom part of the section have vesicle trails at a high angle to the core and some elongate vesicles on the same trend. There is some minor yellow and gray alteration on the pieces from middle part, and the bottom piece has a thin coating of brown alteration. 


\subsubsection{Site BMS-07}

Core BMS-07-01 Sulfide chimney material with pyrite as the dominant mineral was recovered. The samples are relatively fresh, although most of the pieces appear somewhat oxidized. Vugs occur throughout and some brownish-orange alteration occurs on the upper surface of the last piece in the section.

Core BMS-07-02 section A Altered (oxidized) pieces of sulfide chimney material were recovered. Alterations to brown and black on the upper surface of the first piece and to brown/orange on the upper surface of the second piece were observed.

Core BMS-07-02 section B Altered (oxidized) pieces of sulfide chimney material, similar to those in the previous section, were recovered. There is a brown alteration surface on of some of the small pieces at the top of the section and black/orange coating on the bottom surface of the piece at middle part of the section. An orange alteration surface occurs on the pieces from lower part of the section.

\subsubsection{Site BMS-08}

Core BMS-08-01 Basalt to andesite lava, which is aphyric with vitric groundmass, was recovered. Alteration to orange-brown mineralization is observed throughout the section.

Core BMS-08-02 Basalt to andesite lava was recovered. The rock is aphyric with a vitric groundmass. A few vesicles occur at the upper part of the section. Much larger vesicles occur in the piece from middle to lower part. Alteration to brown mineralization affects the top two pieces in the section. There is also an orange-brown coating on the surface of the piece from the lower part of the section and a brown alteration coating on the top and bottom of the last piece in the section. Pale gray alteration halos surrounding the brown alteration were also observed on this last piece.

Core BMS-08-03 Basalt to andesite lava was recovered. The rock is aphyric with a vitric groundmass and a few vesicles especially in the middle part of the section. There is brown to black alteration on pieces throughout the section. There is also orange-brown mineralization that occurs in distinct layers in the last piece in the section.

\subsubsection{Site BMS-09}

Core BMS-09-01 Sulfide chimney material was recovered. Red-brown alteration on fracture surfaces is observed especially on the last three large pieces in the section.

Core BMS-09-02 section A Breccia/conglomerate of pieces of sulfide mixed with basalt/andesite were recovered . Sulfides form the dominant cementing agent. The lava pieces, cemented by sulfide, contain a variety of secondary mineralization products as amygdules and as vein fillings. Pyrite is the dominant sulfide, but chalcopyrite and other sulfides are also present.

Core BMS-09-02 section B Sulfide chimney material and breccia/conglomerate of pieces of sulfide chimney material with much less basalt/andesite in them were recovered. As in the previous section, the dominant sulfide is pyrite. Toward the bottom of the section, the sulfide appears darker, suggestive of more oxidizing.

Core BMS-09-03 Small fragments of sulfide chimney materials were recovered. The pieces are similar to the previous section.

\subsection{Bulk-Rock Geochemistry}

\subsubsection{Analytical Procedures}

A total of 28 samples (17 BMS core samples and 11 surface samples) from the Snail, Yamanaka, Archaean, and Pika hydrothermal sites were analyzed. Sampling positions of the surface samples are summarized in Table 41.2. Major element analyses for all the samples were carried out by X-ray fluorescence techniques (XRF) at Senshu University in Japan or by inductively coupled plasma mass spectrometry with alkali fusion digestion (FS-ICPMS) at Actilabs in Canada. Trace elements were analyzed for 11 BMS samples by FS-ICPMS at Actilabs in Canada. For XRF analysis, compositions were determined using glass beads fused in a gold-platinum crucible at $1,150{ }^{\circ} \mathrm{C}$. The glass beads were made from ignited sample powders mixed well with $\mathrm{Li}_{2} \mathrm{~B}_{4} \mathrm{O}_{7}$ flux in a 1:5 proportion following the method described by Sato (2010).

\subsubsection{Major and Trace Element Characteristics of the Rock Samples}

Bulk-rock major and trace element data for the drill core samples recovered by BMS, together with the surface samples collected using the manned submersible SHINKAI6500 and ROV ROPOS, are given in Suppl. 41.1. In this section, we focus on chemical characteristics of basement rocks rather than sulfide ores. Petrological and geochemical features of the sulfide ore samples 
Table 41.2 List of surface rock samples used in this study

\begin{tabular}{|c|c|c|c|c|}
\hline \multirow[b]{2}{*}{ Sample ID } & \multirow[b]{2}{*}{ Date } & \multicolumn{2}{|l|}{ Position } & \multirow[b]{2}{*}{ Water depth } \\
\hline & & Latitude & Longitude & \\
\hline \multicolumn{5}{|l|}{ Snail site } \\
\hline 6K1227R02 & $9 / 13 / 2010$ & $12^{\circ} 57.1089^{\prime} \mathrm{N}$ & $143^{\circ} 37.0889^{\prime} \mathrm{E}$ & 2,848 \\
\hline $6 \mathrm{~K} 904 \mathrm{R} 3^{\mathrm{a}}$ & $8 / 2 / 2005$ & $12^{\circ} 57.1980^{\prime} \mathrm{N}$ & $143^{\circ} 37.0980^{\prime} \mathrm{E}$ & 2,852 \\
\hline \multicolumn{5}{|l|}{ Yamanaka site } \\
\hline 6K1227R06 & $9 / 13 / 2010$ & $12^{\circ} 56.7686^{\prime} \mathrm{N}$ & $143^{\circ} 36.6955^{\prime} \mathrm{E}$ & 2,849 \\
\hline R774-0004 & $3 / 20 / 2004$ & $12^{\circ} 57.021^{\prime} \mathrm{N}$ & $143^{\circ} 37.059^{\prime} \mathrm{E}$ & 2,861 \\
\hline $\mathrm{R} 774-0006^{\mathrm{b}}$ & $3 / 25 / 2004$ & $12^{\circ} 53.6376^{\prime} \mathrm{N}$ & $143^{\circ} 36.7962^{\prime} \mathrm{E}$ & 2,828 \\
\hline R779-0002 ${ }^{b}$ & $3 / 25 / 2004$ & $12^{\circ} 56.660^{\prime} \mathrm{N}$ & $143^{\circ} 36.789^{\prime} \mathrm{E}$ & 2,827 \\
\hline \multicolumn{5}{|l|}{ Archaean site } \\
\hline 6K1221R02 & $9 / 5 / 2010$ & $12^{\circ} 56.2201^{\prime} \mathrm{N}$ & $143^{\circ} 37.8993^{\prime} \mathrm{E}$ & 3,082 \\
\hline 6K1223R01 & $9 / 7 / 2010$ & $12^{\circ} 56.3575^{\prime} \mathrm{N}$ & $143^{\circ} 37.7758^{\prime} \mathrm{E}$ & 3,050 \\
\hline 6K1224R01 & $9 / 9 / 2010$ & $12^{\circ} 56.4677^{\prime} \mathrm{N}$ & $143^{\circ} 38.0250^{\prime} \mathrm{E}$ & 3,059 \\
\hline \multicolumn{5}{|l|}{ Pika site } \\
\hline 6K1222R04-01 & $9 / 6 / 2010$ & $12^{\circ} 55.2007^{\prime} \mathrm{N}$ & $143^{\circ} 38.7425^{\prime} \mathrm{E}$ & 2,876 \\
\hline 6K1226R01 & $9 / 12 / 2010$ & $12^{\circ} 55.2962^{\prime} \mathrm{N}$ & $143^{\circ} 39.0282^{\prime} \mathrm{E}$ & 2,917 \\
\hline
\end{tabular}

${ }^{\text {a }}$ Samples were collected by SHINKAI6500 during YK05-09 cruise conducted in September, 2005 by Yokosuka

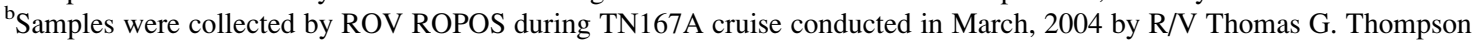

Other samples were collected by SHINKAI6500 during YK10-11 cruise conducted in September, 2010 by Yokosuka

recovered by BMS are described in elsewhere in this book (Ishibashi et al., Chap. 23).

On the total alkalis vs. silica diagram (Fig. 41.4a), most of the on-axis samples from the Snail and Yamanaka sites plot within the basaltic andesite field, whereas all off-axis samples from the Archaean, and Pika sites have higher silica abundances, falling within the field of andesite. In the silica vs. $\mathrm{K}_{2} \mathrm{O}$ diagram (Fig. 41.4b), all the samples lie between the low-K tholeiite field and medium-K calc-alkaline field, showing that these samples are relatively depleted in alkali elements.

Multi-element diagrams normalized to N-MORB display noticeable enrichment of fluid-mobile elements such as Cs, $\mathrm{Rb}, \mathrm{Ba}, \mathrm{U}$, and $\mathrm{K}$ with remarkable negative $\mathrm{Nb}$ and $\mathrm{Ta}$ anomaly (Fig. 41.5). This clearly suggests significant introduction of a subduction component into their parent magmas, which is consistent with the results of Pearce et al. (2005). Elemental abundances are relatively high in off-axis samples, compared with on-axis samples. This reflects the more evolved features (high concentrations of $\mathrm{Si}$ and alkali elements) of off-axis samples shown in major element compositions (Fig. 41.4a). In chondrite-normalized REE patterns, off-axis samples exhibit relatively higher REE abundances with minor negative $\mathrm{Eu}$ anomalies, compared with on-axis samples (Fig. 41.6). This also suggests that the off-axis lavas are more evolved with crystal fractionation of plagioclase.
In Fig. 41.7, major element versus $\mathrm{MgO}$ variation diagrams are shown for the drill core and surface samples, together with volcanic rocks sampled from the other regions of SMT (Masuda and Fryer, Chap. 21). Most of the elements show positive or negative correlation with $\mathrm{MgO}$ contents, which can be related to general fractionation trends of volcanic rocks in the SMT (Fig. 41.7). More precisely, the on-axis samples (Snail and Yamanaka) and the Archaean samples seem to lie on a straight line. On the other hand, the Pika samples clearly show departure from the line (Fig. 41.8). The trace element data also show essentially the same tendency (Fig. 41.9), although the number of samples plotted in the minor element versus $\mathrm{MgO}$ variation diagrams is significantly smaller than those in the major element diagrams (Figs. 41.7 and 41.8). This result suggests the difference in magmatism between the Pika site and the other three sites. This leads us to consider that the basement rocks of the Archaean hydrothermal site are a differentiated product of on-axis magma, whereas those of the Pika hydrothermal site are not directly related to the on-axis magma (might be related to off-axis magmatism). This interpretation of rock chemistry is generally consistent with geographical features of the two offaxis hydrothermal vent sites; the Archaean site hosted by small seamounts at the foot of the spreading axis whereas the Pika site situated on a relatively large off-axis seamount (Fig. 41.2). 
Fig. 41.4 Silica versus (a) total alkali and (b) $\mathrm{K}_{2} \mathrm{O}$ diagrams with fields after Le Maitre et al. (1989) and Rickwood (1989),

respectively, illustrating the major element composition of

BMS core and surface samples from the Snail, Yamanaka, Archaean, and Pika hydrothermal vent sites
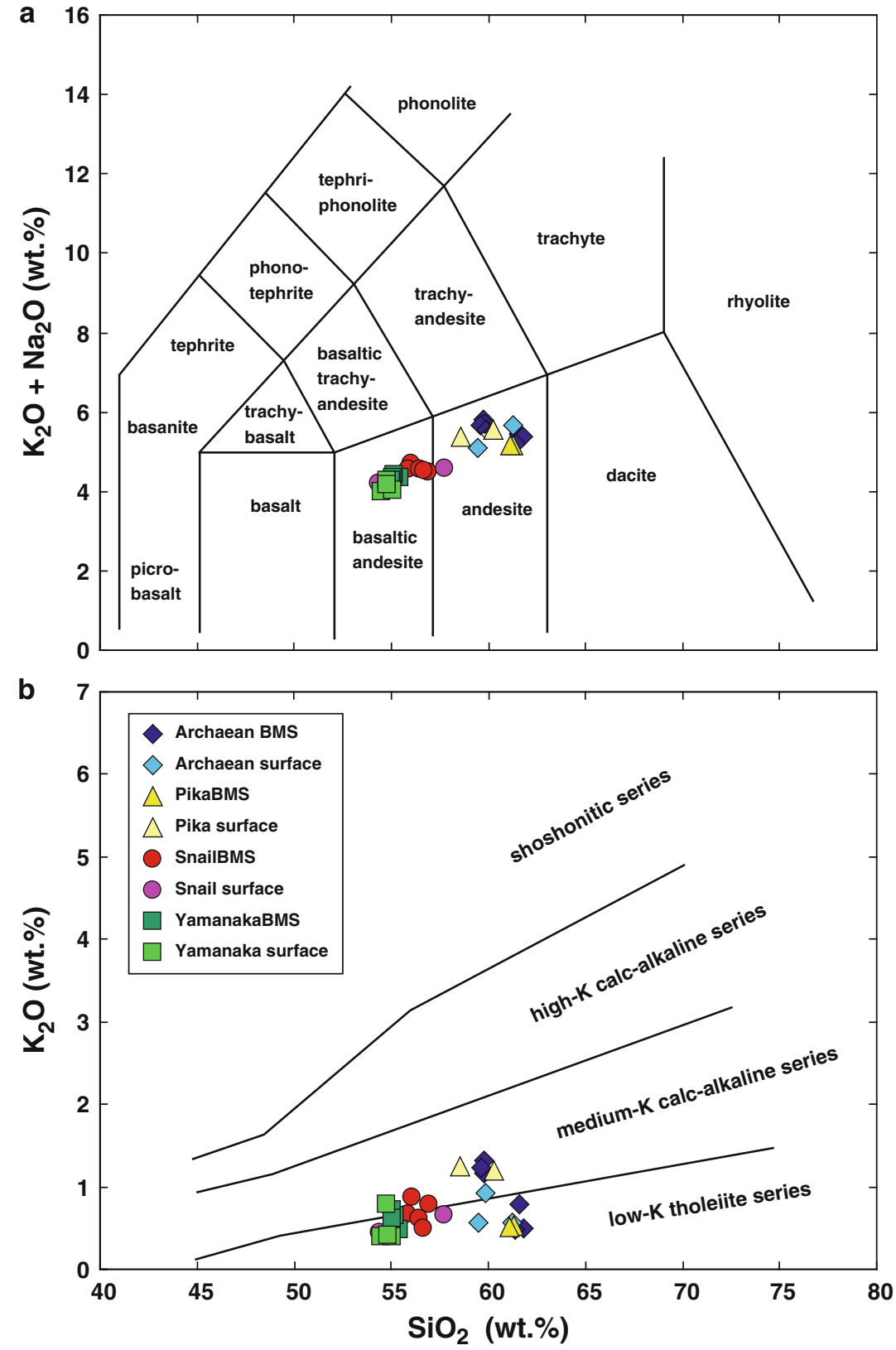
Fig. 41.5 N-MORB-normalized trace element patterns for BMS core samples from the Snail, Yamanaka, Archaean, and Pika hydrothermal vent sites.

Normalizing values are after Sun and McDonough (1989)
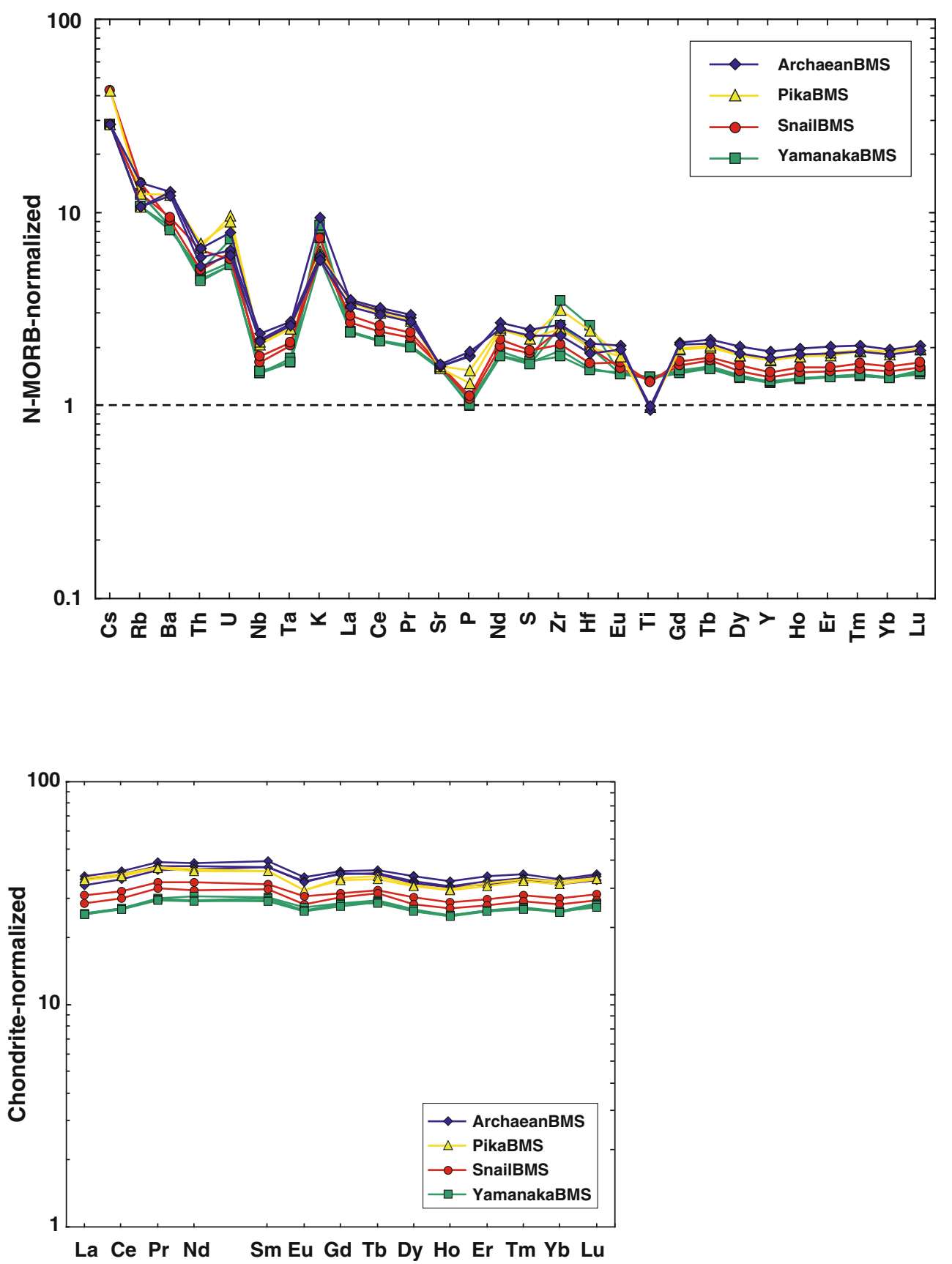

Fig. 41.6 Chondrite-normalized rare-earth element patterns for BMS core samples from the Snail, Yamanaka, Archaean, and Pika hydrothermal vent sites. Normalizing chondrite values are after Anders and Grevesse (1989) 

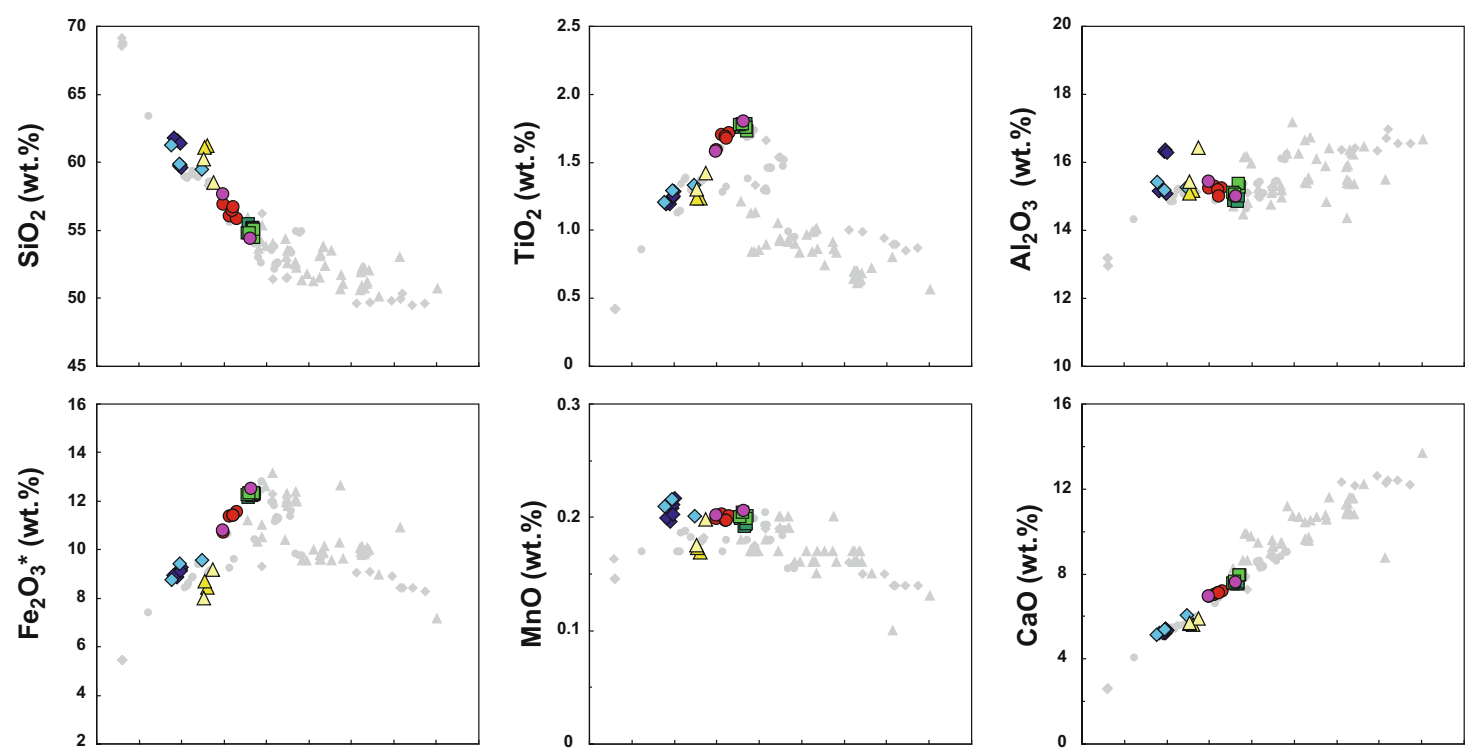

$\diamond$ ArchaeanBMS

$\diamond$ Archaean surface

$\triangle$ PikaBMs

$\triangle$ Pika surface

- SnailBms

O Snail surface

$\square$ YamanakaBMS

$\square$ Yamanaka surface

ridge

off-axis

arc-seamount
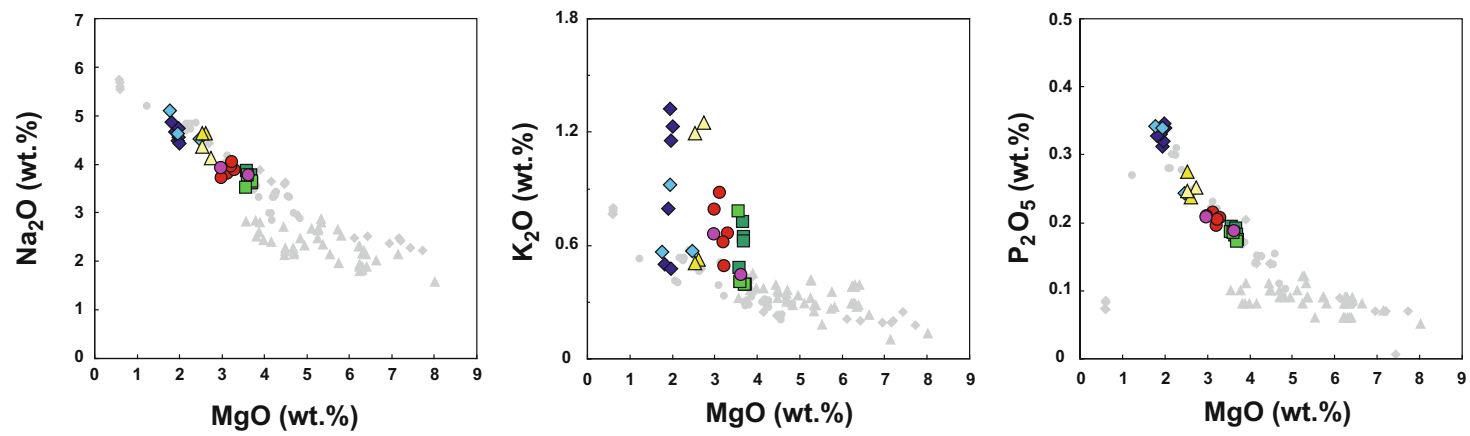

Fig. 41.7 Variation diagrams of major elements vs $\mathrm{MgO}$ for BMS core and surface samples from the Snail, Yamanaka, Archaean, and

region, and arc-seamounts reported in Masuda and Fryer, Chap. 21 Pika hydrothermal vent sites. Surface samples from ridge axis, off-axis 

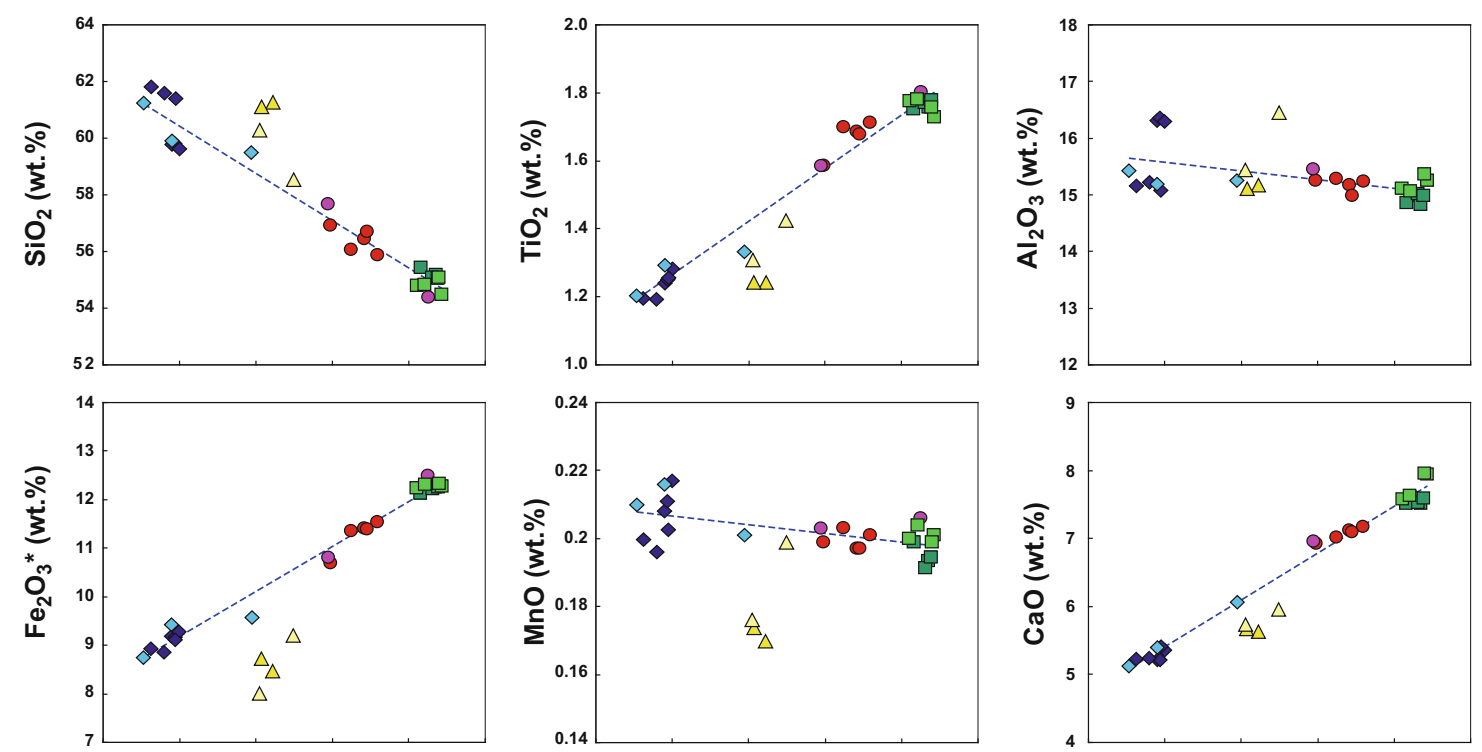

ArchaeanBMS

$\diamond$ Archaean surface

$\triangle$ PikaBMs

$\triangle$ Pika surface

- SnailBMS

- Snail surface

๑ YamanakaBMS

$\square$ Yamanaka surface
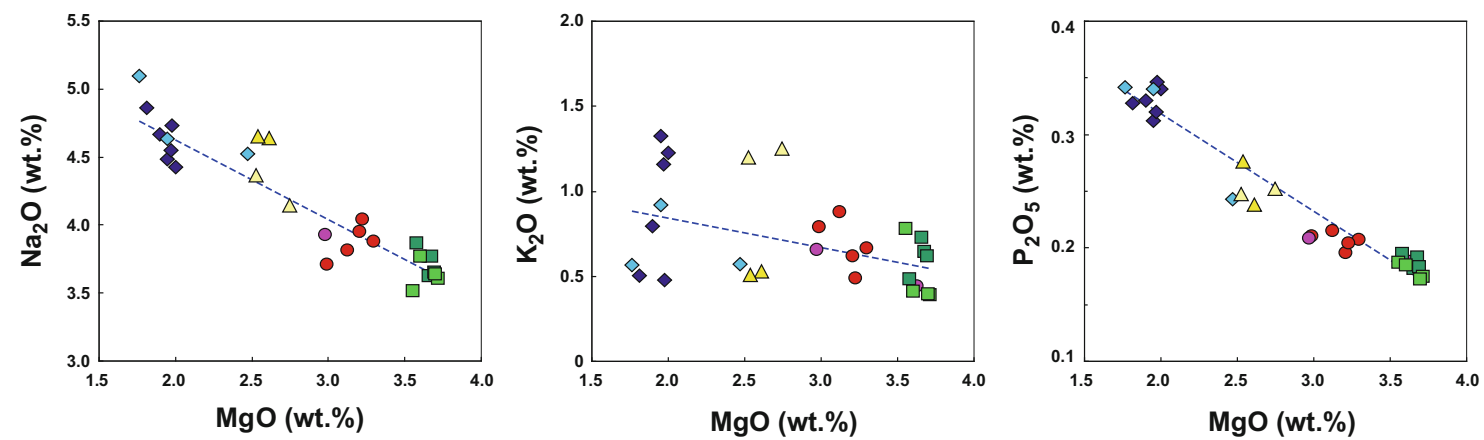

Fig. 41.8 Variation diagrams of major elements vs MgO for BMS core and surface samples from the Snail, Yamanaka, Archaean, and Pika hydrothermal vent sites. Dotted lines represent regression lines for Archaean, Snail, and Yamanaka data 

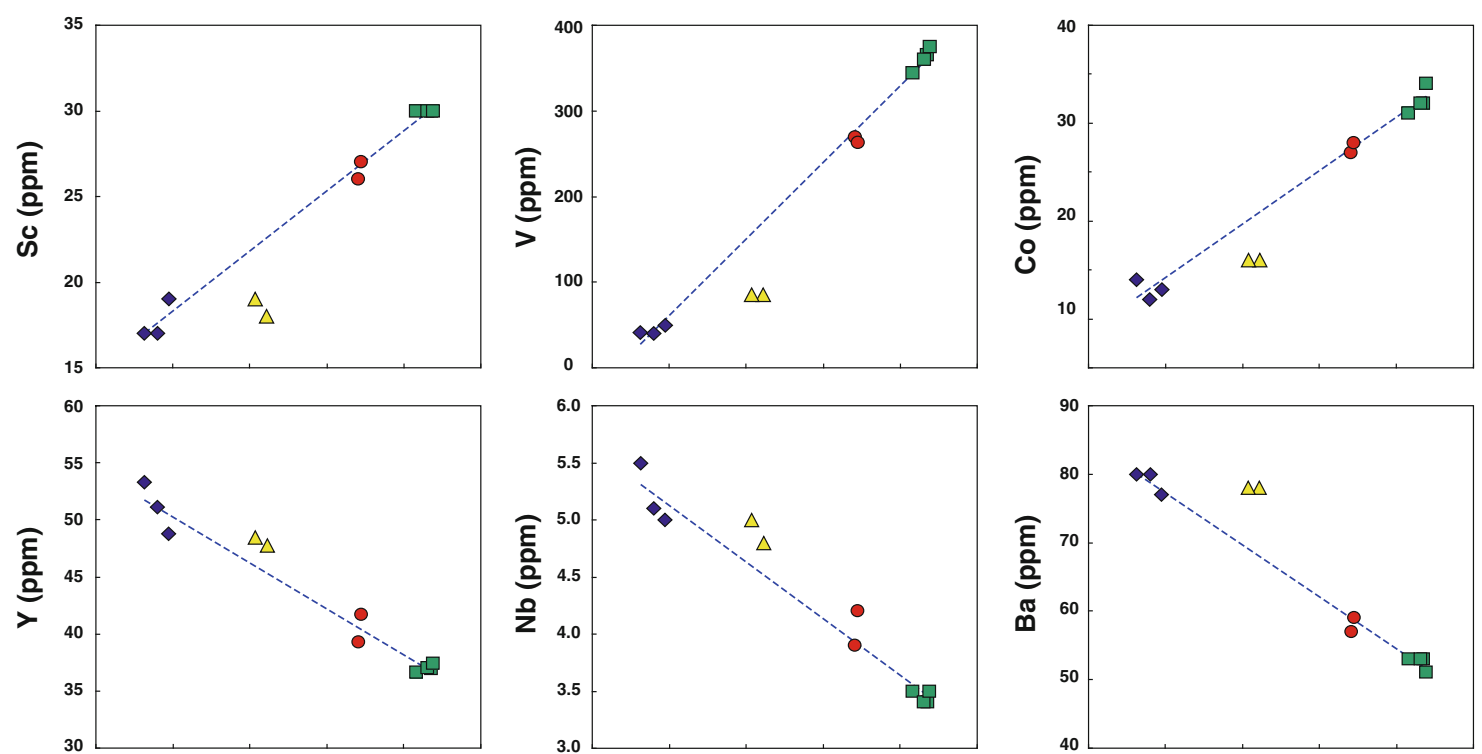

$\diamond$ ArchaeanBMS

$\triangle$ PikaBMS

- SnailBMS

$\square$ YamanakaBMS
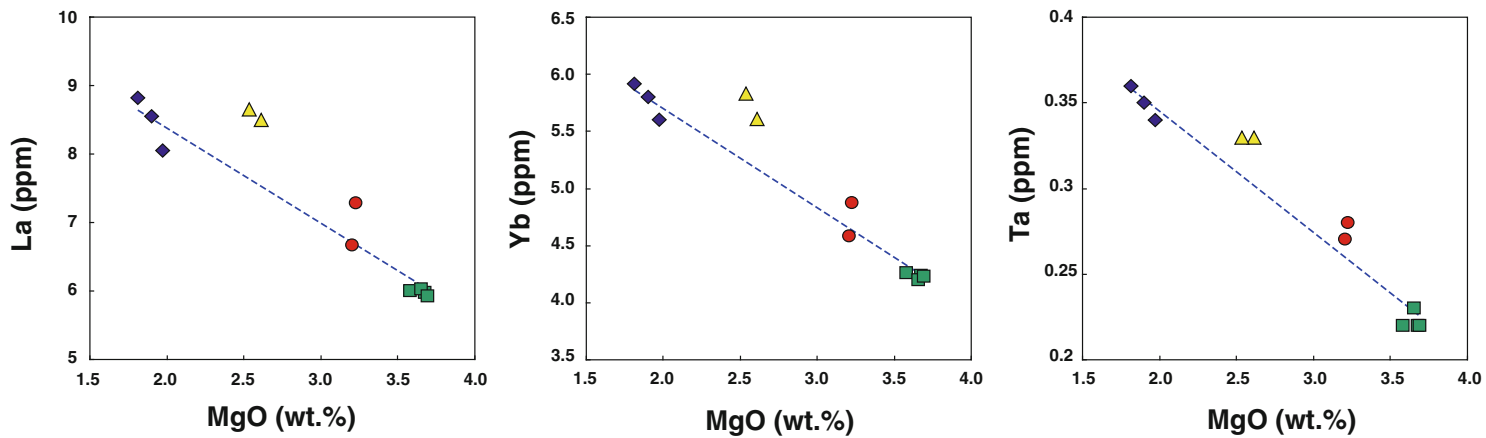

Fig. 41.9 Variation diagrams of minor elements vs $\mathrm{MgO}$ for BMS core samples from the Snail, Yamanaka, Archaean, and Pika hydrothermal vent sites. Dotted lines represent regression lines for Archaean, Snail, and Yamanaka data

Acknowledgments We thank the BMS operation team led by Mr. Tokuro Kobayashi for the perfect and marvelous operation of BMS and Captain Morio Endo and the crew of the R/V Hakurei-Maru No.2 for their skillful support during the TAIGA10M cruise. Thanks are also due to Ms. Keiko Komiyama for preparation of XRF samples. The constructive and helpful review by an anonymous reviewer is gratefully acknowledged. This research was financially supported by the Ministry of Education, Culture, Science, and Technology (MEXT) of Japan, through a special coordination fund (Project TAIGA: Trans-crustal Advection and In situ biogeochemical processes of Global subseafloor Aquifer).

Open Access This chapter is distributed under the terms of the Creative Commons Attribution Noncommercial License, which permits any noncommercial use, distribution, and reproduction in any medium, provided the original author(s) and source are credited.

\section{References}

Anders E, Grevesse N (1989) Abundance of the elements: meteoritic and solar. Geochim Cosmochim Acta 53:197-214

Becker NC, Fryer P, Moore GF (2010) Malaguana-Gadao ridge: identification and implications of a magma chamber reflector in the southern Mariana Trough. Geochem Geophys Geosyst 11: Q04X13. doi:10.1029/2009GC002719
Edmond JM, Measure CI, McDuff RE, Chan LH, Collier R, Grant B, Gordon LI, Corliss JB (1979) Ridge crest hydrothermal activity and the balances of the major and minor elements in the ocean: the Galapagos data. Earth Planet Sci Lett 46:1-18

Elderfield H, Schultz A (1996) Mid-ocean ridge hydrothermal fluxes and the chemical composition of the ocean. Annu Rev Earth Planet Sci 24:191-224

Hessler RR, Kaharl VA (1995) The deep-sea hydrothermal vent community: an overview. In: Humphris SE, Zierenberg RA, Mullineaux LS, Thomson RE (eds) Seafloor hydrothermal systems: physical, chemical, biological, and geological interactions, vol 91, Geophysical monograph series. AGU, Washington, pp 72-84

Kobayashi K, Nakada M (1979) Magnetic anomalies and tectonic evolution of the Shikoku inter-arc basin. In: Uyeda S, Murphy R, Kobayashi $\mathrm{K}$ (eds) Geodynamics of the western pacific, vol 6, Advances in earth sciences. Japan Scientific Society, Tokyo, pp 391-402

Le Maitre RW, Bateman P, Dudek A, Keller J, Lameyre J, Le Bas KJ, Sabine PA, Schmid R, Sorensen H, Streckeisen A, Woolley AR, Zanettin B (1989) A classification of igneous rocks and glossary of terms: recommendations of the international union of geological sciences, subcommission on the systematics of igneous rocks. Blackwell, Oxford, p 193

Martinez F, Fryer P, Becker NC (2000) Geophysical characteristics of the southern Mariana Trough, $11^{\circ} 50^{\prime} \mathrm{N}-13^{\circ} 40^{\prime} \mathrm{N}$. J Geophys Res 105:16591-16607 
Nakamura K, Toki T, Mochizuki N, Asada M, Ishibashi J-I, Nogi Y, Yoshikawa S, Miyazaki J-I, Okino K (2013) Discovery of a new hydrothermal vent based on an underwater, high-resolution geophysical survey. Deep Sea Res I 174:2-10

Pearce JA, Stern RJ, Bloomer SH, Fryer P (2005) Geochemical mapping of the Mariana arc-basin system: implications for the nature and distribution of subduction components. Geochem Geophys Geosyst 6:Q07006. doi:10.1029/2004GC000895

Rickwood PC (1989) Boundary lines within petrological diagrams which use oxides of major and minor elements. Lithos 22:247-263

Sato H (2010) Quantitative analyses with X-ray fluorescence analyzer of major elements for rock samples. Bull Inst Nat Sci Senshu Univ 41:15-23 (in Japanese)

Seno T, Maruyama S (1984) Paleogeographic reconstruction and origin of the Philippine Sea. Tectonophys 102:53-84
Seyfried WE Jr, Ding K, Berndt ME (1991) Phase equilibria constraints on the chemistry of hot spring fluids at mid-ocean ridges. Geochim Cosmochim Acta 55:3559-3580

Shock EL (1992) Chemical environments of submarine hydrothermal systems. Orig Life Evol Biosph 22:67-107

Sun S.-S, WF. McDonough (1989) Chemical and isotopic systematics of oceanic basalts: implications for mantle composition and processes. In: Saunders AD, Norry MJ (eds) Magmatism in the ocean basins. Geological Society London, vol 42. Special Publication, pp 313-345

Tivey MK (2007) Generation of seafloor hydrothermal vent fluids and associated mineral deposits. Oceanography 20:50-65

Urabe T, J. Ishibashi, A. Maruyama, K. Marumo, N. Seama, and M. Utsumi (2004) Discovery and drilling of on- and off-axis hydrothermal sites in back-arc spreading center of southern Mariana Trough, western Pacific. Eos Trans AGU 85(47), Suppl, Abstract V44A-03, Dec 2004 